\title{
HISTORIC PRESERVATION AND COMMUNITY DEVELOPMENT IN AN AMERICAN COLLEGE TOWN
}

\section{AMERIKA'DA BİR KOLEJ KASABASINDA TARIHII KORUMA VE TOPLUMSAL KALKINMA}

\author{
Makale Bilgisi Article Info \\ Bašvuru: 5 Haziran 2020 Received: June 5, 2020 \\ Hakem Değerlendirmesi: 8 Haziran 2020 Peer Review: June 8, 2020 \\ Kabul: 26 Haziran 2020 Accepted: June 26, 2020 \\ DOI : 10.22520/tubaked.2020.21.001
}

James K. REAP *

\section{ABSTRACT}

Athens, Georgia is the quintessential American college town, home to the first state-chartered university in the United States. While its cultural heritage has suffered from development, particularly in the latter half of the twentieth century, it has retained much of its character by employing available public and private historic preservation tools. This paper explores how some of those tools have been utilized by government, nonprofit organizations and private individuals and enterprises, including survey, planning, listing, economic incentives, and protection through government regulation, private law devices, and public education. The role of nonprofit organizations, the University of Georgia, and local government are highlighted. Maintaining community character as the community continues to develop and grow will be an ongoing challenge, but current tools, along with new approaches, can be applied to achieve that end.

Keywords: United States, historic preservation, survey, listing, incentives, regulation.

\footnotetext{
Prof. Dr., Historic Preservation Program College of Environment \& Design University of Georgia 285 South Jackson Street Athens, GA 30602 USA

e-posta: jreap@uga.edu ORCID: 0000-0003-1821-0332
} 


\section{ÖZET}

Atina, Amerika Birleşik Devletleri’nde ilk devlet üniversitesine sahip olan tipik bir Amerikan kolej şehridir. Kentsel gelişimle ilişkili olarak kentin kültürel mirası özellikle yirminci yüzyılın son yarısından itibaren olumsuz yönde etkilenmiş olsa da, kamu ve özel sektörde yer alan mevcut kültürel mirası koruma araçlarının kullanımı ile kentin kültürel mirasının çoğu korunmuştur. Bu makale; devlet, kâr amacı gütmeyen kuruluşlar, özel kişi ve kurumlarca yürütülen anket, planlama, tescil etme, özel hukuki çözümler ve eğitimleri de içeren uygulamaların kültürel mirası korumaya olan katkılarının nasıl olduğunu araştırmaya odaklanmaktadır. Makalede özellikle kâr amacı gütmeyen kuruluşların, Georgia Üniversitesi'nin ve yerel yönetimin rolleri vurgulanmaktadır. Sonuç olarak, makalede, toplumsal gelişim ile kültürel mirasın korunması arasındaki zorlukların aşılabilmesi için koruma araçlarının yeni yaklaşımlarla birlikte ele alınıp uygulanması değerlendirilmektedir.

Anahtar Kelimeler: Birleşik Devletler, tarihi koruma, tespit, tescil, teşvikler, tüzük. 


\section{INTRODUCTION}

The story of Athens, Georgia began in 1784, only months after a treaty was signed ending the American Revolutionary War. In that year, the legislative body of the newlycreated State of Georgia set aside land to endow "a college or seminary of learning". The following year, the state became the first in the United States to charter a public university. However, it was not until 1801 that a committee was charged with finding a site and erecting buildings. They chose a place on the Oconee River in the northeastern part of the state, far from the nearest town of any size, and ambitiously called it "Athens", for the classical center of culture in Greece. Land was quickly cleared, and buildings were constructed for the beginning of classes. The first class graduated in 1804, but it was not until 1806 that a permanent building, now called Old College, was completed. Lots were laid out for a town, and the income from the sale and rental of these lots and other lands owned by the university provided the primary income for the college (Figures 1 and 2).

The town and university developed together throughout the early years with the university dominating the town's character (Coulter 1983; Dyer 1985) ${ }^{1}$ but by the middle of the nineteenth century the community had also become an industrial, commercial, and transportation hub for Northeast Georgia (Figure 3).

Together the university and city have shared progress and growth despite war, depression, politics and natural disaster. The rough settlement of 1801 has developed into a thriving community of over 125,000 residents today with a diversified economy still shaped by its history of education, industry and transportation ${ }^{2}$ (Figures 4 and 5).

Coulter, E. Merton. College Life in the Old South. Brown Thrasher Books, University of Georgia Press, 1983, and Dyer, Thomas G. The University of Georgia: A Bicentennial History, 1785-1985. University of Georgia Press, 1985.

2 Athens was the county seat of Clarke County, the smallest of Georgia's counties at 121 square miles. In January 1991 the two governments were consolidated as a result of a public referendum. References in this paper to Athens after 1991 are to Athens-Clarke County.

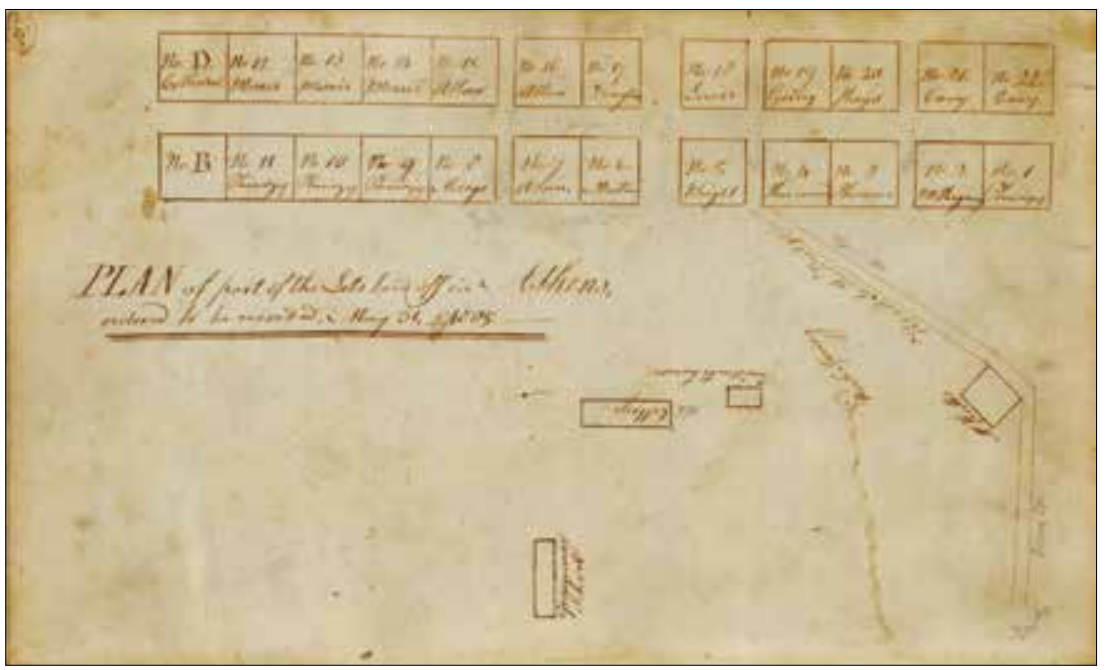

Figure 1. The first known map of the town and college, drawn in 1804. Shown are the spring, the wooden grammar school, the president's house, and the brick College building, then under construction. The note that this was "Old" College was added at a later date. (Courtesy of Hargrett Rare Book and Manuscript Library / University of Georgia Libraries). / Eski kolejin 1804 yılında çizilmiş bilinen ilk haritası. Ahşap gramer okulu, rektör konutu, tuğla kolej binası görülmektedir.

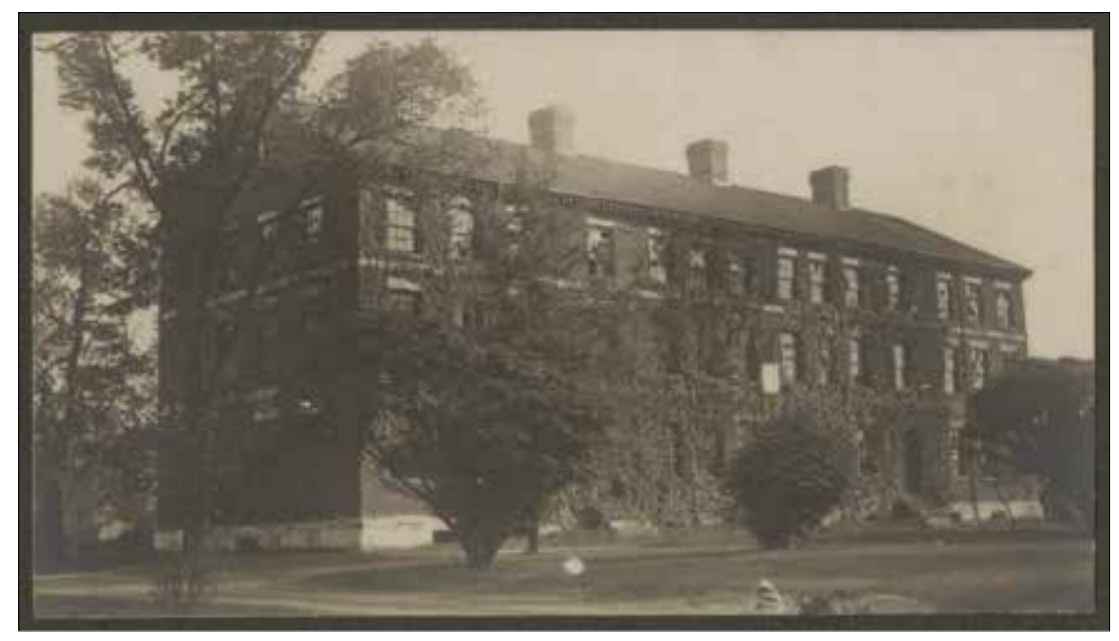

Figure 2. Old College, circa 1806. This view shows the building circa 1908 as abandoned and threatened with demolition. University alumni rallied to save the university's oldest building in Athens' first preservation effort. It was again renovated to celebrate its bicentennial in 2006. Courtesy of Hargrett Rare Book and Manuscript Library / University of Georgia Libraries. / Eski kolej, 1806. Görsel binanın ylkılma tehdidi sebebiyle boşalmış olduğu 1908 yllındandır. Üniversite mezunlarının, üniversitenin en eski binasını korumak için yaptıkları yürüyüş Atina'da ilk kültür varlı̆̆ını koruma çabası olarak ele alınmaktadır. 2006 yılında yapının iki yüzüncü yılı kutlamaları çerçevesinde renovasyonu gerçekleştirilmiştir.

The community developed rapidly with the growth of the university after World War II. Its unique character, attractiveness, and tradition were in danger of being lost in the 1960s when Athens rushed to modernize. Urban renewal and unregulated growth threatened both the city's appearance and way of life. By the $1970 \mathrm{~s}^{3}$, however, the

\footnotetext{
There were earlier examples such as the preservation of Old College by the University in 1906 and the acquisition of the historic Joseph Henry Lumpkin House by the Athens Woman's Club in 1919.
} 


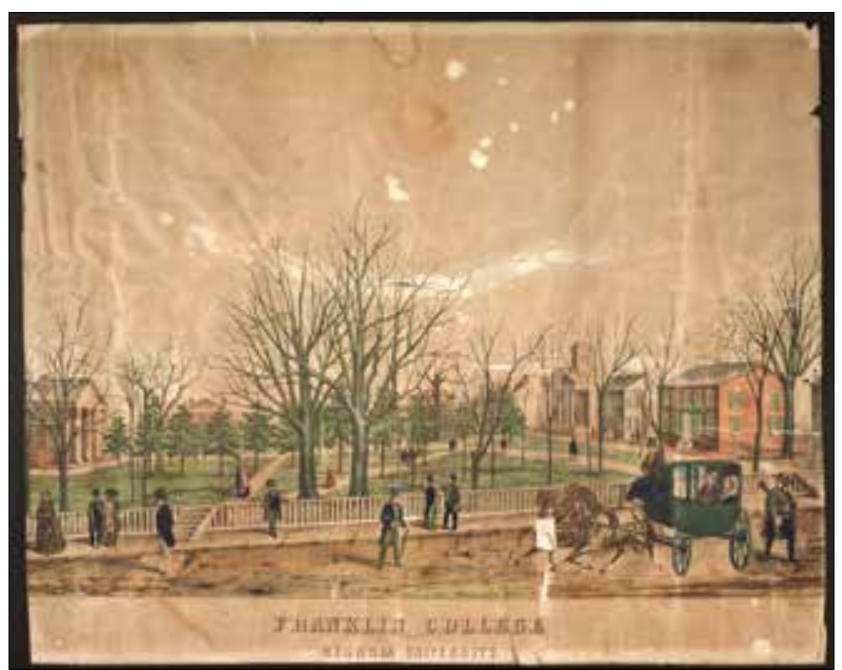

Figure 3. Dr. Louis Moore lithograph of the University of Georgia, circa 1854. This lithograph has many similarities with the betterknown print from Gleason's Pictorial of May 13, 1854 but is more realistic and may have been a model for the more stylized view. (Courtesy of Hargrett Rare Book and Manuscript Library / University of Georgia Libraries.) / Georgia Üniversitesi'nin Dr. Louis Moore litografi. Bu litograf, Glebson'in 13 Mayı 1854 tarihli daha iyi bilinen ve gerçekçi baskısıla birçok benzerliği bulunmaktadır

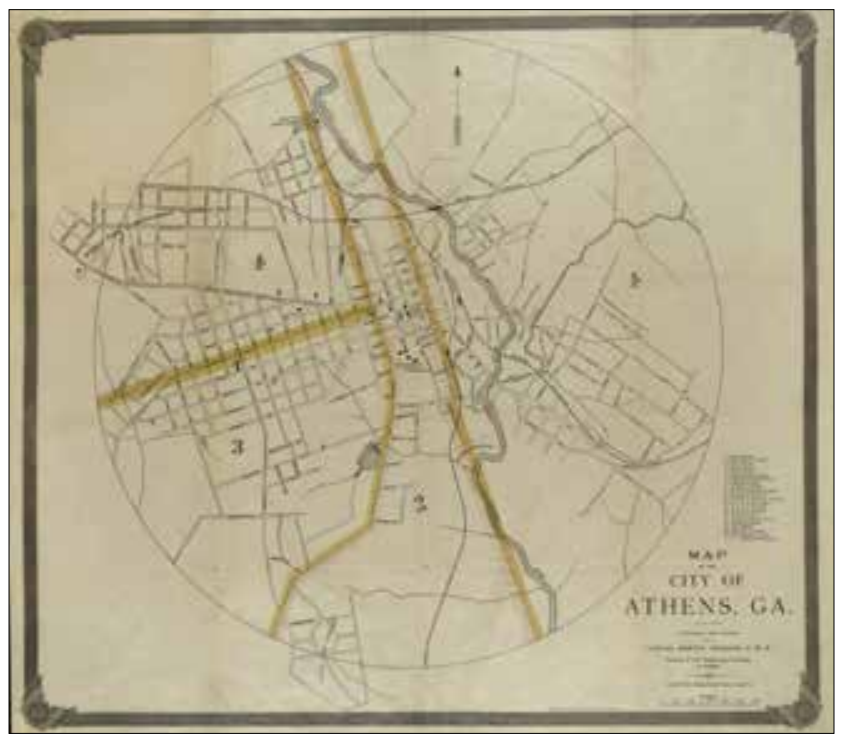

Figure 4. 1893 Map of Athens surveyed and drawn by Charles Morton Strahan, Professor of Civil Engineering, University of Georgia. (Courtesy of Hargrett Rare Book and Manuscript Library / University of Georgia Libraries.) /1893 tarihli Atina Haritası. Tespit ve çizimi Georgia Üniversitesi, Inş̧aat Mühendiliği Profesörü Charles Morton Strahan tarafindan yapılmıştır.

city had begun to rediscover its unique identity in its historic structures and traditions (Reap 2001). Today it is possible for residents, students, and visitors to enjoy both heritage and contemporary development, but retaining that balance requires continual work and application of a variety of economic incentives and regulatory tool (Figure 6).
College towns are a distinct type of community in the United States in which the college or university has a dominant influence over community character. Universities in large metropolitan areas or cities containing other distinct institutions such as state capitals do not fall within this definition because the influence of the academic institution is diminished. The population of college towns trend toward youthful and highly educated, with many residents employed or engaged in the education sector. They are relatively cosmopolitan and unconventional with a diverse, transient population. There is often a higher percentage of rental housing, walking, and commuting by bicycle, food co-ops and liberal voting patterns than in surrounding areas. Although each college town is physically unique, many share a number of characteristics. University campuses are public spaces as well as learning environments, serving as landscaped parks, cultural centers, and historic sites. Commercial districts in these towns are also distinctive, with many businesses targeting a student or young adult clientele. Older neighborhoods have often undergone radical transformations as student populations have grown and sought nearby off-campus housing, particularly since World War II. However, a number of college towns retain a good share of their distinctive historic neighborhoods (Gumprecht 2003: 51-80).

Athens reflects many of these characteristics and, in spite of the growth and development it has experienced, particularly in the past fifty years, it retains many important aspects of its cultural heritage.

Interest in cultural heritage conservation or, as it is more commonly referred to in the United States, historic preservation, has grown from a relatively small group of individuals and organizations interested in history and culture to be embraced by a wider segment of the population concerned with economic development and sustainability. It has also developed from an activity largely driven by private individuals and nonprofit groups to one that also engages the government and private sector. As this evolution occurred, the number and variety of tools and techniques employed by preservationists increased, embracing public education and advocacy, government regulation, and economic incentives. This national pattern has been repeated in Athens.

Heritage conservation exists, of course, within a national legal framework. The United States' Constitution is based on the premise that power should not be concentrated in one person or group, or in one place. Power at the federal government level is divided among three branches of government: the executive (President), legislative (Congress) and judicial (federal courts). Power is also shared among the different levels of government: federal, state, and local. The federal Constitution specifies which powers are granted to the federal government, such as 


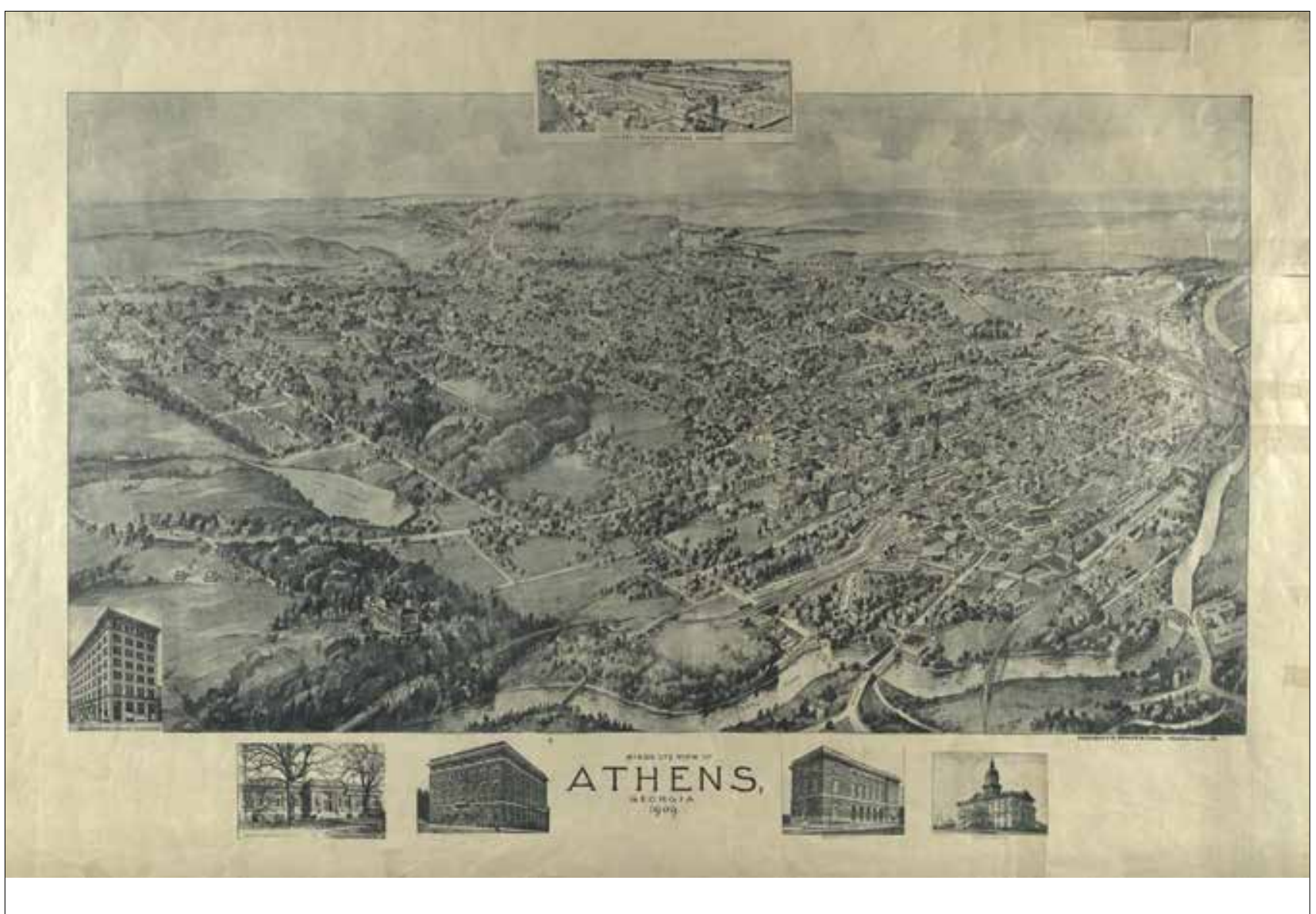

Figure 5. Birds Eye View of Athens, issued by Fowler \& Downs, Morrisville, Pennsylvania, 1909. The panoramic artist, Albert E. Downs, produced a remarkably accurate view. Buildings remaining today are visible, and images of lost features are vivid. Courtesy of Hargrett Rare Book and Manuscript Library / University of Georgia Libraries. / Atina'nın kuş bakışı görünümü. Günümüzde ayakta kalan yapılar ve kaybolanlar anlaşılmaktadır.

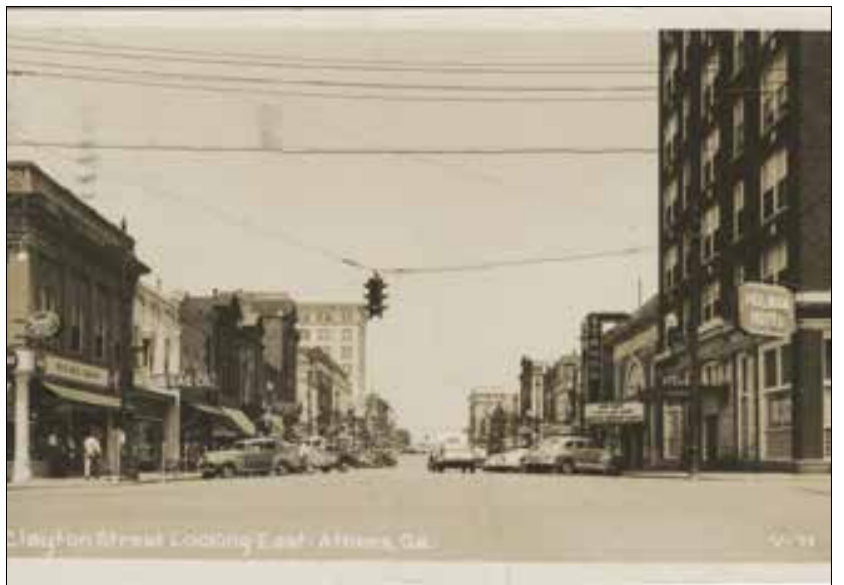

Figure 6. Downtown Athens, circa 1948, a view from the intersection of Clayton and Lumpkin Streets. Courtesy of Hargrett Rare Book and Manuscript Library / University of Georgia Libraries. / 1948 yulında Clayton ve Lumpkin Sokaklarının kesişiminden bir görünüm.

defense, foreign relations, and currency regulations, for example. However, the Constitution also limits the power of the federal government and the Tenth Amendment further specifies that, "The powers not delegated to the United States (i.e., the federal government), nor prohibited by it to the states, are reserved to the states respectively, or to the people" (X Amendment $)^{4}$.

Each state has its own constitution, which specifies which powers the state may exercise, and which powers are delegated to local governments. The relationship between states and local governments is very complex and differs from state to state. Local governments have no inherent power of their own - their authority comes from the state. Some states have given broad powers to local governments while others have given more limited powers ${ }^{5}$.

Among the powers traditionally reserved to the states is the so-called "police power", a concept derived from Anglo-Saxon law. This is the inherent authority of the state to regulate, protect and promote the public health, safety, morals, and general welfare. Exercising

4 "X Amendment", Legal Information Institute, Cornell University, accessed May 20, 2010, https://www.law.cornell. edu/constitution/tenth amendment.

5 "Local US Governments," National League of Cities, accessed May 10, 2020, https://www.nlc.org/local-us-governments. 
this power, states have enacted laws regulating the use of land and have delegated some of their authority to local governments. Many local governments, in turn, have enacted local planning, zoning and historic preservation laws. The U.S. Supreme Court has held that the power to protect buildings and areas with special historic, architectural, or cultural significance is a legitimate use of the police power ${ }^{6}$.

The movement to preserve historic places began in earnest at the local level. First came private initiatives focused on individual monuments, like efforts in the nineteenth century to preserve Mount Vernon, the home of the first President, George Washington. In the early 1930s the City of Charleston, South Carolina was the first local government to adopt a law for the protection of a heritage area - its historic district. Many local governments in the ensuing decades followed this approach. The United States government, while enacting some laws affecting historic resources, did not enact comprehensive preservation legislation until 1966. Even that effort resulted from a study sponsored by the U.S. Conference of Mayors that looked at European models to help formulate a national approach $^{7}$. The National Historic Preservation Act of 1966 established a partnership among the federal, state, and local governments, introducing a new comprehensive program with national standards and economic incentives without pre-empting existing state and local legislation. It was designed, in fact, to encourage states and local governments to develop robust preservation programs of their own. As history has demonstrated, preservation has never been the exclusive domain of government in the United States. Well-preserved communities are almost always the result of the combined efforts of government, private individuals, businesses and corporation, and nonprofit organizations. This paper will illustrate how this approach has been followed in Athens as each of the actors in the process have utilized a variety of approaches, alone and together in the effort to preserve the community's historic character as a part of promoting sustainable economic development.

\section{SURVEY, INVENTORY AND LISTING OF HERITAGE PROPERTIES}

In order to effectively plan for the protection of a community's historic environment, it is essential to know what properties exist and understand their significance. The first step is a survey - the process of gathering and recording data on historic resources that involves planning, background

\footnotetext{
Penn Central Transportation Co. v. New York City, 438 U.S. 105 (1978)

7 With Heritage So Rich, New York (Random House, 1966).
}

research, organization, evaluation, presentation of data and development of inventories (National Register Bulletin 24). One of the earliest national efforts to identify important historic buildings was the Historic American Buildings Survey (HABS) which began in 1933 as part of an effort to address the effects of the Great Depression. It's mission was formalized the following year through a cooperative agreement among the National Park Service, American Institute of Architects, and the Library of Congress (Tyler, Norman, Ilene and Ligibel 2018: 47). The program was expanded over the years to include the Historic American Engineering Record (HAER) and the Historic American Landscapes Survey (HALS). The collection now includes 581,000 measured drawings, photographs, and written histories of more than 43,000 historic structures and sites from Pre-Columbian era to the twentieth century. Thirtythree properties in Athens and Clarke County, including on the University of Georgia campus, have been documented by this program over the years, forming the basis of the community's documentation of important heritage places $^{8}$ (Figure 7).

In 1935, Congress passed the Historic Sites Act which gave the National Park Service the authority to inventory historic and archaeological properties and identify those of national significance. The National Survey of Historic Sites and Buildings employed a logical and thematic approach focusing on broader aspects of American history rather than the previous practice of preserving sites for primarily patriotic reasons. Suspended during World War II, the survey was given new life and expanded focus of recognizing a diverse set of properties possessing national significance reflecting all themes of American history with the goal of encouraging their preservation by both private and public owners. This effort resulted in the establishment of the National Historic Landmark (NHL) program in $1960^{\circ}$. Today there are nearly 2,600 NHLs located listed throughout the United States. One such property is located in Athens - the Robert Taylor-Henry W. Grady House. Build in the mid-1940s, the Greek Revival House was included in the HABS survey of Athens in 1937. It remained in private ownership until being purchased by the City of Athens in 1966 after standing vacant and vandalized for 13 years. Two years later the City leased the house later to the Athens Junior Assembly (now the Junior League of Athens), a nonprofit women's

\footnotetext{
Historic American Buildings Survey/Historic American Engineering Record/Historic American Landscapes Survey, accessed May 10, 2020, https://www.loc.gov/pictures/ collection/hh/, and Linley, John. The Georgia Catalog, Historic American Buildings Survey: A Guide to the Architecture of the State. Publications / The Wormsloe Foundation: V. 15. University of Georgia Press, 1982.

9 "Roots of the National Historic Landmarks Program", National Park Service, Accessed May 25, 2020, https://www.nps.gov/ articles/roots-of-the-national-historic-landmarks-program.htm.
} 


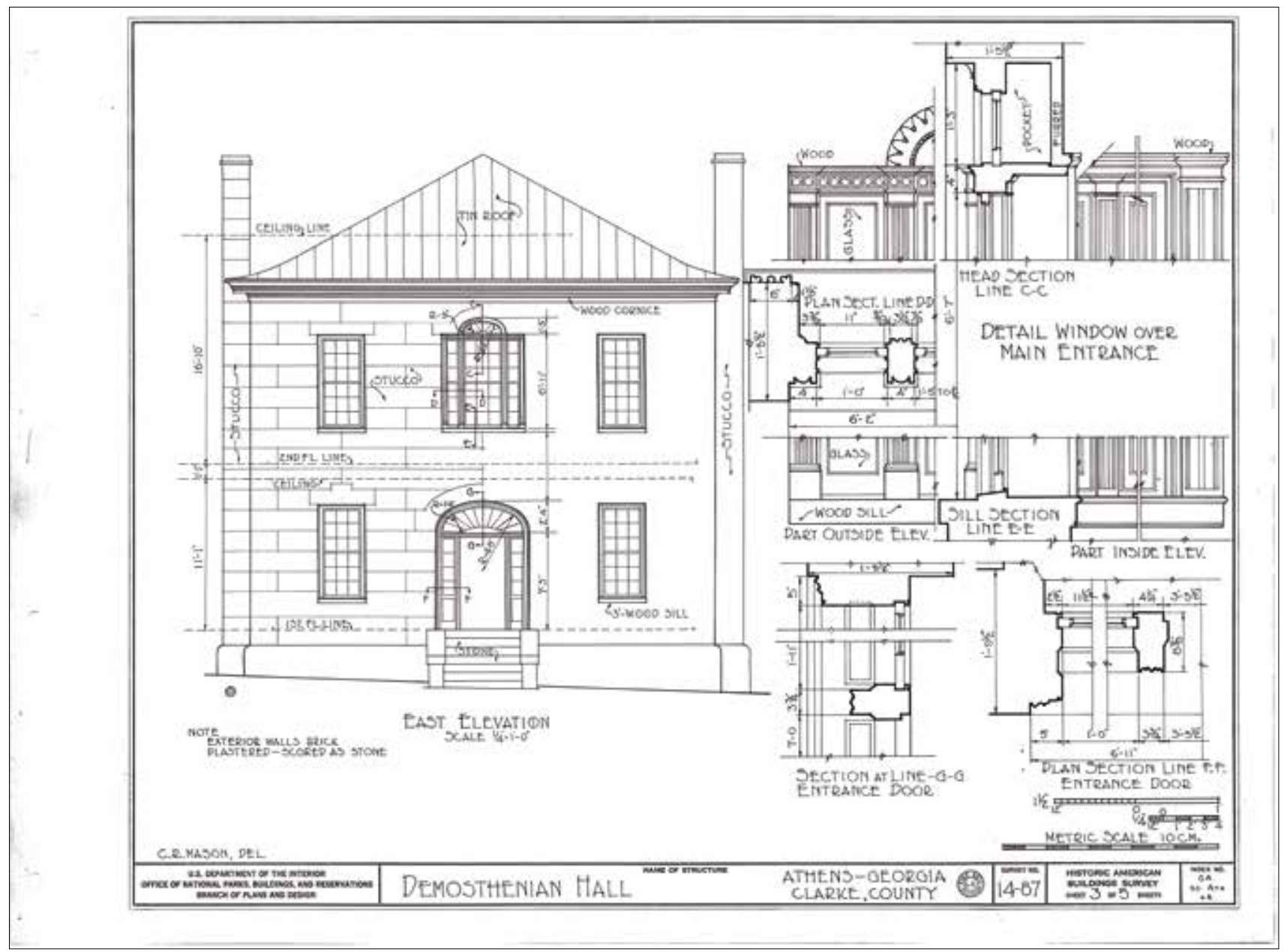

Figure 7. University of Georgia Demosthenian Hall recorded by the Historic American Buildings Survey, compiled after 1933. Library of Congress, Prints \& Photographs Division, HABS, Reproduction number HABS GA,30-ATH,4A- (sheet 3 of 5). / Georgia Üniversitesi, Demosthenian Salonu. 1933 yılında yapılan Tarihi Amerikan Yapıları tespiti sonrasında kaydedilmiștir.

organization focusing on community improvement through volunteerism and leadership. The Junior League restored the house and continues to maintain it as a museum house and event venue open to the public. The house is considered significant for its association with Henry W. Grady, editor of the Atlanta Constitution newspaper in the years following the Civil War and advocate for economic development and industrialization of the South following its defeat in the war. His famous "New South" speech delivered in New York in 1886 was widely circulated and quoted and helped to advance reconciliation between the North and South ${ }^{10}$. In the case of the Taylor-Grady House, its recognition of significance in these surveys contributed to the local efforts for its preservation. (Figure 8)

In 1976, a local non-governmental organization, the Athens-Clarke Heritage Foundation, conducted a selective survey of 797 buildings constructed in Athens

$\overline{10}$ Georgia NHL Henry W. Grady House, National Archives Catalog, accessed May 20, 2020, https://catalog.archives.gov/ id/93206752. prior to 1900. Focusing on residences, the survey also included commercial and institutional resources, excluding smaller buildings. The survey sheets included information on the ownership, use, architect/builder, value, exterior appearance, date of construction, style, physical condition, and an evaluation of significance along with a black and white photograph. In subsequent years, the Foundation participated in numerous survey and documentation efforts alone or in partnership with state or city governments.

In passing the National Historic Preservation Act of 1966 (NHPA), the U.S. Congress recognized that a key prerequisite of an effective preservation program was identification of historic resources through comprehensive surveys. Resources were provided to states to conduct statewide surveys, and when the act was amended in 1980, Congress mandated increased assistance from the states to local governments that has been used, in part, to conduct or update local surveys ${ }^{11}$.

$\overline{11}$ Established under the Historic Sites Act of 1935, 16 U.S.C. $\S \S$ 


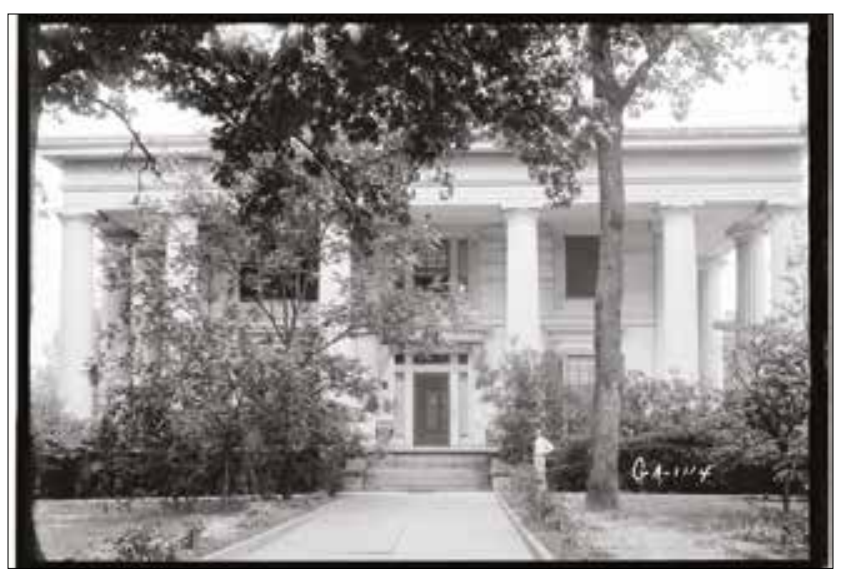

Figure 8. Robert Taylor-Henry W. Grady House, circa 1845. Photograph by L.D. Andrew, 1936, Library of Congress, Prints \& Photographs Division, HABS, Reproduction number HABS GA,30-ATH,8-2. / Robert Taylor-Henry W. Grady Evi, 1945.

In 1975, the Historic Preservation Division of the Georgia Department of Natural Resources (DNR) employed a consultant to conduct a survey which documented 229 buildings in Clarke County. The survey was selective, containing photographs and minimum documentation. In the late 1970s and early 1980s, the Athens-Clarke Heritage Foundation received a matching grant from the Department of Natural Resources to survey several historic areas of Athens in order to facilitate completion of nominations of several National Register districts, including Downtown Athens, Cobbham, Bloomfield, Boulevard, Milledge Avenue Milledge Circle, Woodlawn, Reese Street Oglethorpe Avenue, and West Hancock. (See National Register, below.) After the passage of the 1980 Amendments to the NHPA, the city of Athens was designated a Certified Local Government (CLG) and received matching grants from DNR under that program in 1988 and 1989. The intensive and comprehensive historic resources survey included more than 1,400 commercial, residential, and institutional properties within the city. Sites were assessed using the Georgia Historic Resource Form which included photographs and more extensive data relating to the owner, site, historical context and significance, and geographical location information cross-reference to county tax maps. Accurate architectural descriptions utilized professional terminology. Copies of the survey were retained by the local planning department and provided to the state. A State-Owned Historic Property Survey (1992) sponsored by DNR and the Georgia Trust for Historic Preservation (a statewide

461 et. seq., and expanded by the National Historic Preservation Act of 1966, as amended, 16 U.S.C. $\S \S 470$ a et. seq.; National Register of Historic Places, National Park Service, accessed May 10, 2020, https://www.nps.gov/subjects/nationalregister/ index.htm. preservation nonprofit organization) and funded by a discretionary grant from the Georgia Governor identified all historic resources owned or leased by the State of Georgia constructed prior to 1943 except for highway bridges and archaeological sites. Eightyfive of the 1,175 properties identified statewide were from Athens (Cullison and Lockart 1993). When completing an intensive study of a major local transportation route, the Prince-Dougherty Corridor Study (2000), a comprehensive survey funded by a CLG grant documented 171 historic properties. This study served as a model for local traffic surveys and transportation planning efforts ${ }^{12}$.

Over the years, the University of Georgia Historic Preservation program has assisted the community by completing several survey projects. In 1995, graduate historic preservation students conducted a preservation planning survey, which was intended to create a methodology for future surveys based on experience in four residential districts. A field study form was developed for speed, but Georgia Historic Resource Forms and photographs were generated to meet state standards. The survey focused on buildings constructed prior to 1940 which retained their architectural integrity. Seven-hundred-eightythree resources were documented. In 1998, historic preservations students completed the New Town, Lickskillet, Barrow/Pulaski Neighborhood Survey as part of an overall revitalization plan for the area ${ }^{13}$.

Involvement of University of Georgia historic preservation students in local surveys efforts is continuing through the FindIt program operated by the University's College of Environment and Design. In 2019 a team of students under professional supervision began surveying all resources over 40 years of age in Athens-Clarke County, starting with areas that were outside the city limits prior to consolidation in 1991 . It is estimated that approximately 10,000 resources will be documented by the project completion date in 2022. FindIT is a state-wide cultural resource survey program sponsored by the Georgia Transmission Corporation in partnership with Georgia DNR. The program teaches students how to conduct fieldwork, architectural identification, mapping, and data analysis while providing the Transmission Corporation with data to assist in in making decisions on power transmission routes ${ }^{14}$.

\footnotetext{
12 Prince-Dougherty Corridor Study - OTF. 2000.

13 "Chapter 4: Natural and Cultural Resources", Community Assessment, Athens Clark County Unified Government, accessed May 10, 2020, https://athensclarkecounty.com/855/ Community-Assessment.

14 "FindIT", College of Environment + Design, University of Georgia, accessed May 10, 2020, https://ced.uga.edu/pso/findit/.
} 
In addition to the surveys described above, individual sites and areas are often the subjects of focused survey efforts in connection with nominations of properties the National Register of Historic Places, environmental reviews of projects utilizing federal and state funds, designation of local historic districts, or other projects requested by the local Historic Preservation Commission. These studies are conducted by city staff, University of Georgia historic preservation students, or consultants utilizing city funds or through sponsorships by non-profit organizations, academic institutions, or government agencies ${ }^{15}$.

\section{DESIGNATION OF HISTORIC RESOURCES}

After historic resources are identified through survey, they are evaluated to determine if they should be designated officially to provide for their recognition and potential protection. The designation process at the national, state, and local levels utilize similar research and evaluation processes, but each system has its own requirements and the results of listing can be different in regard to protection.

The National Historic Preservation Act of 1966 provided for a national inventory of heritage properties - the National Register of Historic Places - the official list of resources in the United States worthy of preservation. The Register comprises buildings, sites, structures, objects, and districts that are significant in American history, architecture, archaeology, engineering, and culture that are of federal, state, or local significance. The program is administered ty the National Park Service under the Secretary of the Interior. To be listed, a property must be historic (generally, at least 50 years old), have a significant portion of its character defining features intact, and meet one or more of the National Register Criteria for Evaluation:

- Association with historic events or activities;

- Association with important persons;

- Distinctive design or physical characteristics (architecture, landscape architecture and/or engineering);

- Or the potential to provide important information about prehistory or history (usually through archaeological investigation $)^{16}$.

The benefits of listing in the National Register include recognition of the property's significance, consideration of the property when there is a potential for federally

\footnotetext{
15 "Chapter 4: Natural and Cultural Resources", 84.

16 Tyler, Historic Preservation, 95; "How to Apply the National Register Criteria for Evaluation”, National Register Bulletin 15, National Park Service, accessed May 10, 2020, https://www. nps.gov/subjects/nationalregister/upload/NRB-15_web508. pd.f.
}

licensed or funded projects to affect the property, eligibility for certain tax benefits, and qualification for a number of federal grants. Importantly, listing does not affect decisions the owner makes regarding the property such as alteration or demolition, unless federal funds or licenses are involved.

In the State of Georgia, the National Register Program is administered by the Historic Preservation Division of the Department of Natural Resources. Proposals from the public for nomination of properties or districts are encouraged. The process, criteria, and forms for submitting a nomination are published on the DNR website. Proposals are evaluated by professional staff, and when all information required by federal guidelines are completed, the nominations are scheduled for review by the Georgia National Register Review Board composed of citizen members with an expertise in historic preservation. The Board gives highest priority to threatened or endangered properties, properties that are receiving tax incentives or grants, districts, and properties associated with minority groups. Next in in consideration are community landmark buildings and publicly owned properties followed by properties that are not threatened or receiving a direct benefit from listing. After approval, the DNR staff prepare the forms and documentation for submission to the Keeper of the National Register in the U.S. Department of the Interior. After a public commenting period and review by the Keeper, the property may be officially listed in the National Register ${ }^{17}$.

The Georgia Register of Historic places is the state's official list of historic properties worthy of preservation. Like the National Register, this program is administered by the Historic Preservation Division of DNR. Listing provides recognition of the properties' significance and ensures that they will be considered in the planning of state-assisted projects. Owners of properties listed in the Georgia Register may be eligible for state tax incentives and properties owned by public agencies or nonprofit organizations may qualify for state grant assistance. Listing does not place restrictions on property owners except those receiving state grants or requesting state tax benefits for an historic property. Requests for Georgia Register listing are reviewed and approved by the same process used for National Register nominations and the same eligibility requirements for listing are applied. Once the nomination is approved by the Georgia National Register Review Board it is listed in the Georgia Register ${ }^{18}$.

\footnotetext{
17 "National Register Nomination Process in Georgia", Georgia Department of Natural Resources, accessed May 10, 2020, https://georgiashpo.org/nominationprocess.

18 "Georgia Register of Historic Places: Recognizing the Preserving Our Historic Properties" (Georgia Department of Natural Resources, 2013).
} 
There were 60 properties in Athens-Clarke County listed in the National and Georgia Registers of Historic Places as of May 15, 2020. The first property in Athens was listed in 1970, the Classic Revival Wilkins House. The most recent listing occurred in 2019, the Chi Omega House, a restrained late example of the Colonial Revival style constructed for 1961 as residence and chapter house for the Chi Omega Sorority. The other listed properties cover a wide range of types and styles that are representative of the history and development of the community. They include residences, commercial and industrial properties, schools, churches, libraries, sorority and fraternity houses, and cemeteries. A number of buildings on the campus of the University of Georgia are included along with several residential, commercial, industrial and educational historic districts ${ }^{19}$. Nominations have been initiated by individuals, neighborhood associations, the nonprofit Athens-Clarke Heritage Foundation, and the Historic Preservation Program at the University of Georgia. While listing in the National Register does not directly protect buildings from destruction, listings in Athens have been utilized as tools for public education and awareness, to qualify the listed structures for tax incentives and grants, and as documentation to support designation by the local government as historic properties or historic districts under local ordinances.

\section{PROTECTION OF HISTORIC PROPERTIES}

While a robust survey and listing programs are key to any local heritage conservation strategy, the strongest mechanism to protect cultural properties in American communities from inappropriate change or destruction is found at the local level. States delegate authority to local governments to enact laws or ordinances for the protection of heritage resources. The specific scope and content of local preservation legislation varies considerably due to the differences among the states in the authority delegated to local governments, community need, and the type of resources protected. Generally, though, preservation ordinances regulate changes that would negatively affect or destroy the character defining features that give designated historic properties and districts their significance. Over 2,000 local governments across the United States have enacted some form of historic preservation ordinance.

In 1980, the Georgia General Assembly enacted the Georgia Historic Preservation Act, establishing uniform guidelines for local governments in creating historic preservation commissions and designating historic

\footnotetext{
19 National Register of Historic Places, accessed May 10, 2020, http://www.nationalregisterofhistoricplaces.com/ga/clarke/ state.html.
}

properties ${ }^{20}$. The City of Athens passed an ordinance under this statewide authorization in 1986, and following the consolidation of governments in 1991 the ordinance also applied to the areas formerly outside city boundaries $^{21}$. The structure of the law is typical of local preservation ordinances in Georgia and elsewhere in the United States. Key provisions include:

- Statement of "purpose" and the legal authority under which the ordinance is enacted.

- Definitions

- Establishment of an historic preservation commission its powers and duties

- The procedure for designation of historic districts and landmarks

- Provisions for adoption of design guidelines to assist the commission in making its decisions ${ }^{22}$

- Statement of actions reviewable by the commission (approval of alteration to historic properties demolition, moving of structures, and new construction), procedures for submission of applications by property owners and criteria for review by the commission, public notice and hearing requirements, permissible decisions and the legal effect of such review

- Appeals from commission decisions

- Maintenance requirements for designated properties

- Procedures for appealing the final preservation commission decision to a higher authority.

- Fines and penalties for violation of ordinance provisions.

The key to actually protecting the properties designated is the design review process in which a property owner applies for a certificate of appropriateness to alter, demolish or move a designated historic property or to construct a new building within an historic district. The historic preservation commission reviews the application and plans and either grants or denies the request after considering whether the project complies with the design guidelines adopted by the community to protect the character-defining features of the historic district tor property involved (Table 1.)

Fifteen historic districts and 45 individual structures or sites have been designated under the local historic preservation ordinance ${ }^{23}$. Other than Downtown

\footnotetext{
20 O.C.G.A. $44-10-20$ et seq.

21 The Code of Athens-Clarke County, Georgia, Chapter 8-5.

22 "Guidelines and Examples", Athens-Clarke County Unified Government, accessed May 10, 2020, https:// athensclarkecounty.com/812/Guidelines-Examples.

23 "Historic Preservation", Athens-Clarke County Unified Government,
} 


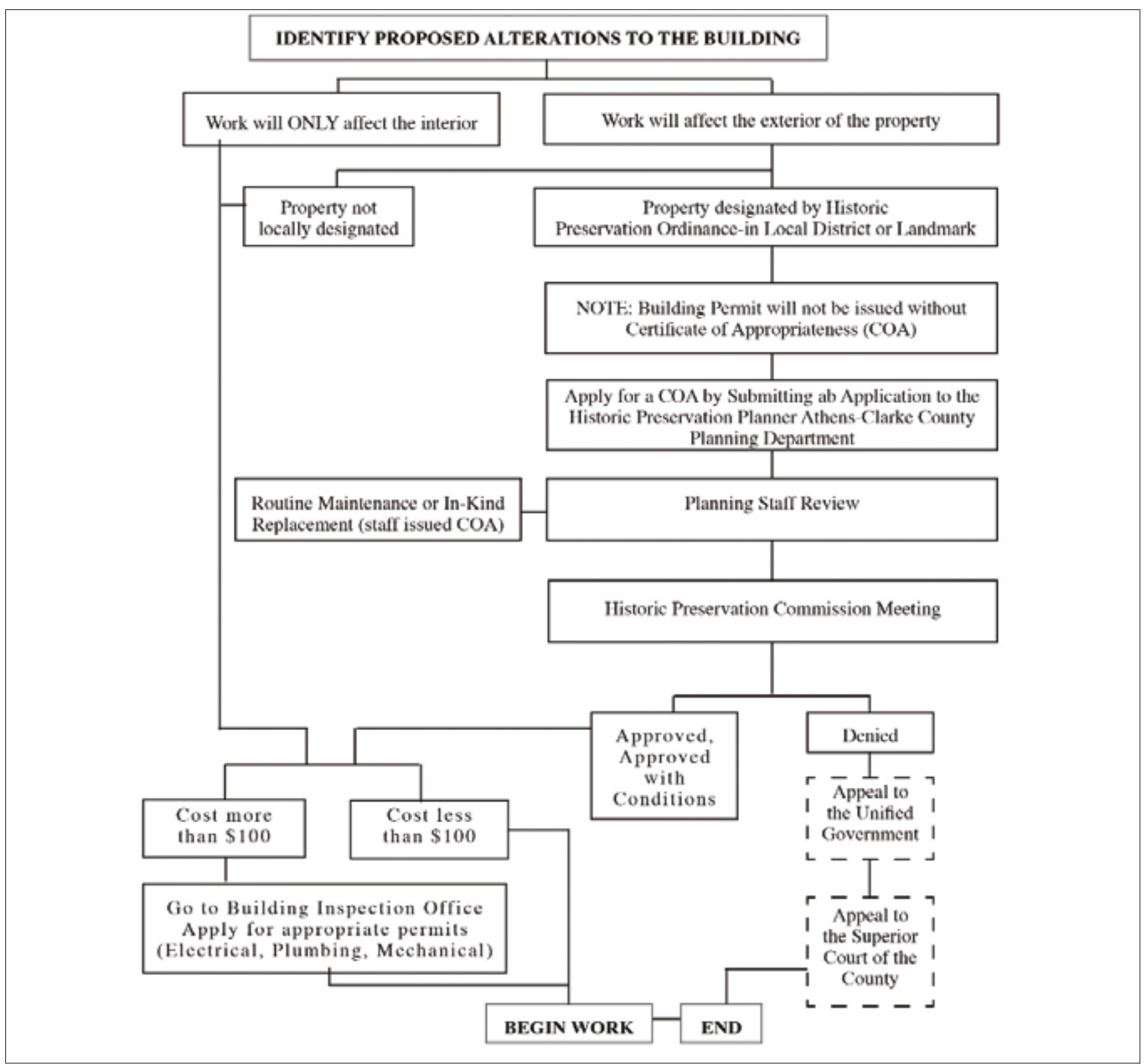

Table 1. Chart illustrating the design review process for proposed construction projects involving properties individually listed or within locally designated historic districts in Athens-Clarke County. https://www.athensclarkecounty.com/DocumentCenter/View/288/HP--Design-Guidelines---Downtown?bidId=. / Atina-Clarke tarihi bölgelerinde ayrı ayrı listelenen veya yerel olarak belirlenmiş mülklere yönelik önerilen yapım projeleriyle ilgili tasarım inceleme sürecinin tablosu.

Athens (the central business district), the designated districts all focus on residential neighborhoods. The individual designated properties are generally outstanding community landmarks, significant buildings that are not in historic districts or were not in historic districts at the time they were designated. In addition to protection through the regulatory process, designated properties can benefit from certain tax incentives, detailed elsewhere in this paper. Research on additional designations are ongoing, and not all properties and districts, listed in or found

accessed May 10, 2020, https://athensclarkecounty.com/208/HistoricPreservation. eligible for listing in the National and Georgia Registers of Historic Places have corresponding local designation. Reasons vary but may include having no local individual or sponsoring organization advocating for their designation, no updated survey of the area, and insufficient financial and human resources on the part local government to undertake the nomination process. In the past, nominations have been undertaken by property owners seeking recognition and/or economic benefits, neighborhood organizations, the local preservation nonprofit organization, or historic preservation students from the University of Georgia (Figure 9). 


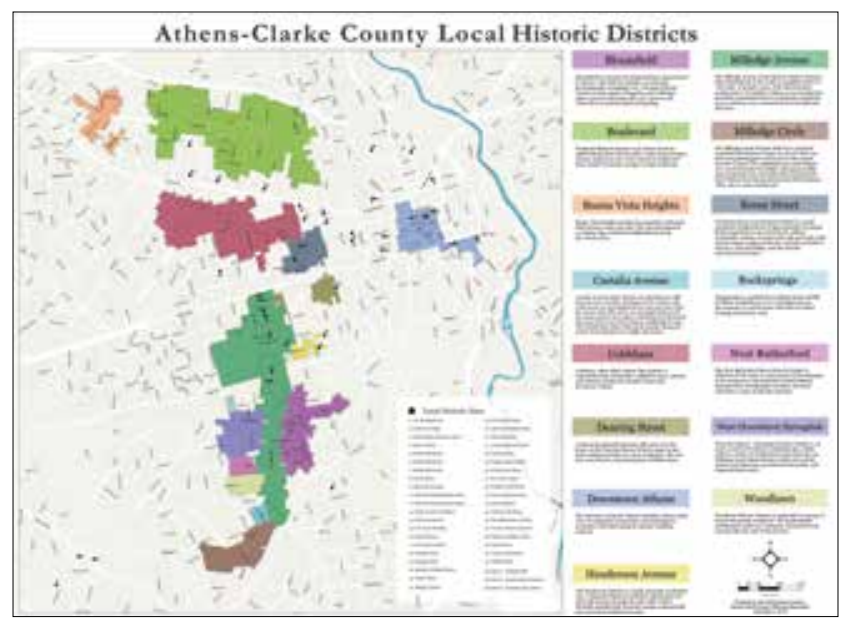

Figure 9. Map of historic districts designated by the AthensClarke County government in which construction is regulated through the Historic Preservation Commission. https://www. athensclarkecounty.com/DocumentCenter/View/19722/HP-Map--Local-Historic-Districts--Landmarks?bidId=. / Atina-Clarke ilçesi yerel tarihi bölgelerin haritast.

\section{PLANNING}

Historic preservation efforts can often be significantly enhanced when the preservation ordinance is closely coordinated with other land use laws and regulations such as those governing comprehensive planning, zoning, and subdivision regulations along with other government programs such as transportation and housing. Many communities throughout the United States have developed formal written preservation plans, reconciling in one document all of the policies and procedures regarding the community's historic resources (Bradford and Richard 1994). The Georgia State Plan, for example, offers a model for developing a local preservation plan ${ }^{24}$. While it is important to have a stand-alone local preservation plan to articulate the preservation goals and objectives of the community, it is even more important that those goals and objectives are incorporated in broader community planning. This helps ensure consideration by other programs such as land use, transportation, and development. The US/ ICOMOS Preservation Charter supports this approach, declaring that the preservation of historic towns and historic districts or areas must be an integral part of every community's comprehensive planning process ${ }^{25}$.

\footnotetext{
24 "State Historic Preservation Plan", Georgia Department of Natural Resources, accessed May 10, 2020, https://georgiashpo. org/statepreservationplan.

25 US/ USICOMOS A Preservation Charter for the Historic Towns and Areas of the (1992). One of the four basic objectives for the preservation of historic towns and areas reads, in part: "Property owners and residents are central to the process of protection and must have every opportunity to become democratically and actively involved in decisions affecting each historic town and district."
}

Georgia was one of the first states to adopt growth management legislation with the passage of the Georgia Planning Act of $1989^{26}$. This law requires each local government in the state to prepare a long-range comprehensive plan. The plan is intended to identify community goals and objectives as well as determine how the local government proposes to achieve them. Ideally it is used in government decision-making on a daily basis. Failure to have an approved plan can result in the loss of state funding for a range of activities. While the scope of growth management is much broader than historic preservation, almost all such legislation includes historic preservation as a goal and/or a required planning element (Listokin 1997) ${ }^{27}$. By including preservation with other key elements, comprehensive planning fosters better coordination between preservation and other land use controls such as zoning. The Georgia law requires that historic resources be considered along with land use, economic development, community facilities, population, housing, and natural resources ${ }^{28}$. In 1996, Athens-Clarke County adopted a historic preservation plan according to the planning standards established by the Georgia Department of Community Affairs under the Georgia Planning Act ${ }^{29}$. The Athens-Clarke County has incorporated historic preservation in all of its comprehensive plans in compliance with Georgia law, including its most recent version adopted in $2018^{30}$.

The University of Georgia, with the largest number of historic buildings of any public university with the state system, completed an historic preservation plan to comply with the 1998 State Stewardship Law which requires that state agencies prepare preservation plans for historic properties for which they are responsible ${ }^{31}$. A primary goal of the plan is to integrate historic preservation and archaeology into early facility planning. The steering committee

26 O.C.G.A. $50-8-1$ et seq.

27 David Listokin, "Growth Management and Historic Preservation: Best Practices for Synthesis”, 29 The Urban Lawyer 202 (1997). Other states with comprehensive planning acts are Delaware, Florida, Hawaii, Maine, Maryland, New Hampshire, New Jersey, Oregon, Rhode Island, Vermont and Washington.

28 Such coordination, while dictated by logic, is frequently absent. There are other advantages. By being part of a comprehensive community plan, preservation can blunt criticism that it is part of the NIMBY ["Not in My Back Yard"] process to stop growth.

29 https://athensclarkecounty.com/DocumentCenter/View/351/ ACC-PreservationPlan_1.

30 "Comprehensive Plan", Athens-Clarke County Unified Government, accessed May 10, 2020, https://www. athensclarkecounty.com/844/Comprehensive-Plan.

31 "State Agency Historic Property Stewardship", O.C.G.A. Section 12-3-55. 


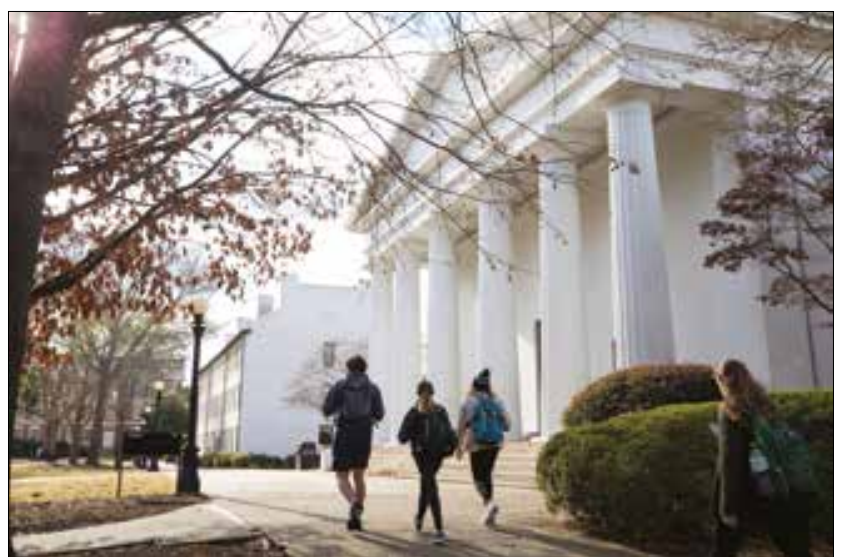

Figure 10. Contemporary view of the historic University of Georgia campus. Buildings, from left to right, Old College (1806), New College, and the Chapel. New College was rebuilt 1832 following a fire and underwent an extensive rehabilitation in 2010. The Chapel was constructed in 1832, making it one of the earliest Greek Revival buildings in Georgia. It is used for a variety of University events and activities. Photo by Dorothy Kozlowski, 2020. Credit University of Georgia Marketing and Communications. / Tarihi Georgia Üniversitesi kampüsünün çağdaş görünümü. Binalar, soldan saga, Eski Kolej (1806), Yeni Kolej ve Şapel. Yeni Kolej 1832'de gerçekleşen yangından sonra yeniden inşa edimiş ve 2010 tılında kapsaml rehabilitasyonu gerçekleşmiştir. Şapel, 1832 yılında inşa edilerek Georgia Üniversitesi'nin en eski Yunan Canlandırması yapısı olmuştur. Yapı, Ünivesite'nin çeşitli etkinlikleri için kullanılmaktadır.

for development of the plan was chaired by the Dean of the College of Environment and Design with overall staff coordination by the university's Director of Historic Preservation. The process started with an historic preservation inventory utilizing historic preservation students under the supervision of faculty and consultants. Students documented each historic structure and cultural landscape which provided data for an electronic database inventory that includes history, context, significance, condition and integrity of each historic property. Workshops were held to engage representatives of the local nonprofit AthensClarke Heritage Foundation, Georgia State Historic Preservation Office and the University System Board of Regents. With the plan in place, the university can follow a process for maintenance and upkeep of historic buildings. It provides a clear set of standard operating procedures for addressing existing historic buildings and landscapes and development of new construction in historic contexts ${ }^{32}$ (Figure 10).

\footnotetext{
32 "Historic Preservation", University of Georgia Office of University Architects for Facilities Planning, accessed May 10, 2020, https://www.architects.uga.edu/home/historicpreservation.
}

\section{PRIVATE PROTECTION - EASEMENTS AND COVENANTS}

While one of the best ways on ensuring the preservation of an historic building is its purchase by a sensitive owner, this approach leaves much to be desired. Its effectiveness depends on the personal whims of the owner, whether they utilize appropriate preservation techniques, and the actions of the owner's heirs or subsequent purchasers when the property is transferred. To address these shortcomings, states have passed legislation that employs elements of private property law to accomplish heritage conservation goals. An important technique for preserving historic buildings is the conservation easement. A conservation easement is a legal agreement between a landowner and governmental agency or nongovernmental organization that permanently restricts future development on a piece of land to protect its key values. These legal devices are in use in every state and currently protect millions of acres of land and many historic structures. Among the non-governmental agencies that commonly utilize this protective tool are nonprofit historic preservation organizations and land trusts, which hold over 17,000 conservation easements (Byers 2005) ${ }^{33}$. Local governments, too, have increasingly established easement programs. Conservation easements are created through a legal document signed by a property owner (called a grantor) and an eligible organization (called a holder) and recorded in the official land records of the political jurisdiction where the property is located. These agreements apply to all future landowners and may be legally enforced.

Easements are appealing because their creation is a private transaction entered into voluntarily by the landowner and the easement-holding organization. The owner either donates an easement (and receives tax incentives for the donation) or sells the easement to the holding organization at a price that is less often than its market value. Since the owner retains restricted use of the land, it remains productive and on the tax rolls while preserving specific conservation values. Conservation easements can protect all kinds of conservation values including, for example, farmland, scenic vistas, historic facades, and sensitive ecological areas.

The Georgia Uniform Conservation Act authorizes the creation of conservation easements in Georgia for the purpose of "preserving the historical, architectural, archaeological, or cultural aspects of real property." The organizations authorized to hold and enforce the easement include governmental bodies as well as charitable

\footnotetext{
Elizabeth Byers, The Conservation Handbook, The Trust for Public Land, 2005, at 8. There are more than 1,300 land trusts in the United States.
} 
organizations that have as a purpose the preservation of such resources. The law specifies that when a legal instrument is recorded in the in court of the county where the land is located, recording serves as notice to the tax assessors to reassess the value of the property to consider any reduction in its value caused by the restriction on the use of the property reflected in the easement ${ }^{34}$. A number of conservation easements have been placed on properties in Athens-Clarke Couny. Examples include the Camak House and the Oconee Street School held by the Georgia Trust for Historic Preservation. Item four of the restriction on the Camak House reads, "No alteration and no physical or structural change and no changes in the material or surfacing shall be made to the exterior of the structure without the prior written approval of the Georgia Trust. Such approval shall be based on plans and specifications provided by Purchaser at Purchaser's expense." Item seven reads: "Neither the building nor any rooms or parts thereof may be removed or demolished without the prior written approval of the Georgia Trust." ${ }_{35}$ Similar conservation easements on the Georgian Hotel and Southern Mill are held by Historic Athens, Inc. Although tax incentives can be a strong motivating factor for easement donation, property owners have been shown to be overwhelmingly influenced by pride in the property and the desire to protect it for future generations. In some cases, the donation of an easement is a stipulation to receive public funding and other tax benefits (Figure 11).

\section{FINANCIAL INCENTIVES}

One financial tool that governments in the United States utilize effectively to incentivize preservation is the tax code. While the federal government has the power to tax, so do the states, which have also delegated some taxing authority to local governments. The combination of tax incentives from the different levels of government can produce significant savings for the property owner who preserves or restores and historic property. Each of the incentives described below has been utilized in Athens.

\section{Income Tax Deductions}

Americans have a financial incentive to make generous contributions to certain nonprofit organizations. When a taxpayer contributes to an organization qualified under Section 501 (c)(3) of the federal income tax code, those donations are deductible on the individual's income tax as charitable contributions. The tax code specifies that to qualify an organization must have purposes such as charitable, religious, scientific, literary, or educational.

\footnotetext{
34 O.C.G.A. Section 44-10-1.

35 Clarke County Georgia Deed Records, Book 1264, Page 128 and Book 4788, Page 26, 2018.
}

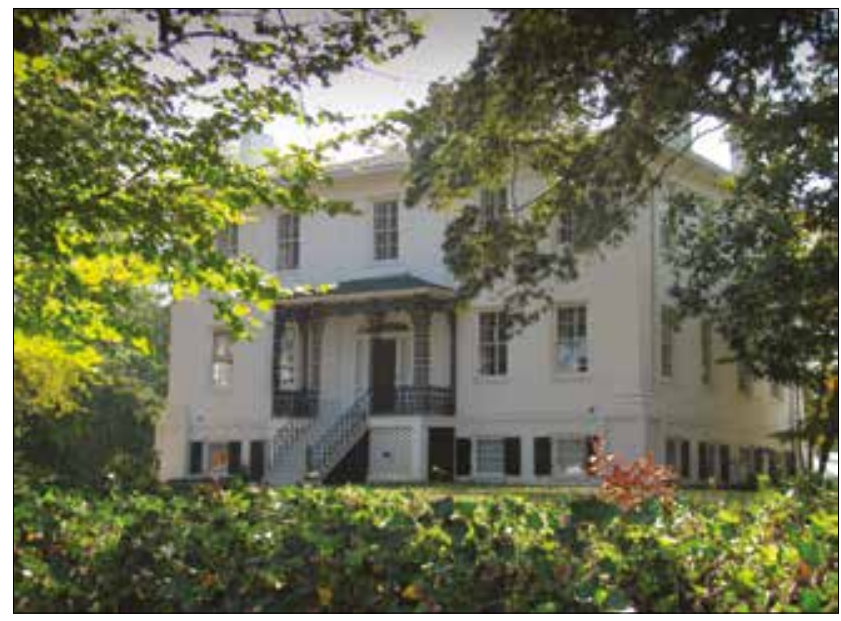

Figure 11. Camak House, 1834. Built by James Camak, one of Georgia's most important early industrialists. Purchased by the Masonic Lodge in 1949, it subsequently served as offices for the Athens Coca-Cola Bottling Company. In the early 1990s the Georgia Trust for Historic Preservation acquired the building and sold it to the law firm of Winburn, Lewis and Barrow, subject to a conservation easement. GAgayle, 27 September 2012, CC BY-SA 3.0. / Camak Evi, 1834. Georgia'nın en önemli ilk sanayicilerinden James Camak tarafindan yaptırılmıştır. 1949 yılınsa Mason Locasi tarafindan satin alınan bina Coca-Cola Şişeleme Şirketi'nin ofisi olarak kullanılmıştır. 1990'lı yılların başlarında, Georgia Tarihi Koruma Vakfi tarafindan satin alınan bina hukuki koruma anlaşmasına tabi tutularak Winburn, Lewis ve Barrow hukuk bürosuna satılmıştır.

They generally receive the majority of their revenue from the general public or the government ${ }^{36}$. Many historic preservation organizations have been able to qualify under this provision and donations are a principal part of their income. Historic preservation activitiespurchase and restoration of historic buildings, operating museums, public education - are all activities that these organizations are authorized to conduct.

The value of conservation easements donated to a nonprofit preservation organization that fall within governmental guidelines are eligible for federal state tax deductions. The value of the easement is based on the difference between the appraised fair market value of the property prior to conveying an easement and its value with the easement restrictions in place. The more the easement restricts the property's development potential, the more valuable it is. In most cases, the easement donor can take a one-time deduction of the value of the easement from his adjusted gross income on which federal taxes income taxes are based. Many states also have provisions that will allow individuals to similarly reduce their state income taxes ${ }^{37}$.

\footnotetext{
36 "Charitable Organizations", Internal Revenue Service, accessed May 20, 2010, https://www.irs.gov/charities-nonprofits/charitable-organizations.

37 "Preservation Easements", National Trust for Historic
} 


\section{Income Tax Credits}

Income tax credits for preservation activities are available under the federal Tax Reform Act of 1986. The act provides for a 20 percent tax credit for the substantial rehabilitation of historic buildings for commercial, industrial, and residential rental purposes. To qualify, both the building and rehabilitation must be certified by the U.S. Department of the Interior. First, the building must be a certified historic structure -- one that is listed in the National Register of Historic Places, located in a National Register historic district, or contained within a district designated by local government that meets certain federal requirements. Second, the rehabilitation activity itself must also qualify. It must be substantial -- costing $\$ 5,000$ or the adjusted basis of the building, whichever is greater. The work done on the building also must be consistent with the historic character of the property and, where applicable, the district in which it is located. The Secretary of the Interior's Standards for Rehabilitation serve as guidelines for determining whether the work is in character ${ }^{38}$. Property owners must complete and submit applications in accordance with federal regulations to the National Park Service through their State Historic Preservation Office in order to receive the credit, and in most cases pay a fee for certification. To avoid repaying all or part of the credit, the owner must retain the property for five years. Since 1976, federal historic preservation tax incentives have leveraged over \$102 billion in private investment and preserved more than 45,000 historic properties. This tax incentive has been one of the nation's most successful and cost-effective revitalization programs, creating jobs and economic activity, enhancing property values, creating affordable housing and increasing tax revenues for governments at all levels while leveraging many times its cost in private expenditures $^{39}$. The Georgia Historic Preservation Division of the Department of Natural Resource assists property owners and reviews applications for these

Preservation, accessed May 20, 2020, https://forum.savingplaces. org/learn/fundamentals/preservation-law/easements; Easements to Protect Historic Properties: A Useful Historic Preservation Tool with Potential Tax Benefits, National Park Service, accessed May 10, 2020 https://www.nps.gov/tps/tax-incentives/taxdocs/ easements-historic-properties.pdf; Federal estate taxes may also be reduced when a property subject to an easement passes by inheritance because the fair market value of the property has been reduced by the easement restrictions.

38 "The Secretary of the Interior's Standards for Rehabilitation", National Park Service, accessed May 10, 2020, https://www. nps.gov/tps/standards/rehabilitation/rehab/stand.htm.

39 "Tax Incentives for Preserving Historic Properties", National Park Service, accessed May 10, 2020, https://www.nps.gov/tps/ tax-incentives.htm; "Federal Tax Incentives for Rehabilitation Historic Buildings: Annual Report for Fiscal Year 2019, National Park Service, accessed May 10, 2020, https://www.nps.gov/tps/ tax-incentives/taxdocs/tax-incentives-2019annual.pdf. credits. Many property owners seek both federal and state credits and these are processed by the State office.

A number of states have enacted state income tax incentives to further encourage preservation. The attractiveness of this incentive to property owners is directly related to the tax rate. Unlike the federal government, state preservation tax credits are often available for owner-occupied residential properties as well as income producing properties. Minimum expenditure requirements and rehabilitation standards are usually key parts of these programs as they are in the federal program. The Georgia State Income Tax Credit Program for Rehabilitated Historic Property, enacted in 2002, allows eligible participants to apply for a state income tax credit equaling 25 percent of qualifying rehabilitation expenses (30 percent for homes in a low-income target area) capped at $\$ 100,000$ for a personal residence. For any other income producing, certified historic structure, the credit is $25 \%$ of rehabilitation expenditures, capped at $\$ 300,000$. Amendments to the law in 2016 established two new categories, capped at $\$ 5$ million and $\$ 10$ million per project with a $\$ 25$ million total program cap for these larger projects. To qualify, properties must be eligible for or listed in the Georgia Register of Historic place either individually or as contributing to an historic district. The rehabilitation must be accomplished in a period of two years, must meet a substantial rehabilitation test, and comply with the Department of Natural Resources' Standards for Rehabilitation. The Program is administered by the Georgia Department of Natural Resources and Georgia Department of Revenue. In 2019 alone, the Department preliminarily certified 90 applications for the rehabilitation of 30 historic homes and 60 income-producing properties, representing investments of more than $\$ 240$ million. When projects are completed, it is estimated that more than 3,000 jobs will be created directly and indirectly generating over $\$ 86$ million in salary and wages. It is expected more than $\$ 7$ million in state tax and $\$ 6$ million in local tax revenues will be generated for sales taxes, property taxes and corporate and other taxes and revenues ${ }^{40}$. Since the program's initiation, applications for 116 properties in Athens have been submitted to the Department of Natural Resources. The types of buildings rehabilitated included a theatre, school, telephone exchange building, restaurants, athletic facility, automobile service facility, industrial buildings, office buildings, apartments, and houses. Properties were put into continuing or new uses as private residences, apartments, offices, commercial establishments, and mixed-use projects ${ }^{41}$. Many of these

\footnotetext{
40 "State Income Tax Credit Program for Rehabilitated Historic Property", Georgia Department of Natural Resources, accessed May 10, 2020, https://georgiashpo.org/tax-statecredit.

41 Molly McLamb, Georgia Department of Natural Resources, in an email message to the author, May 20, 2020.
} 
projects combined state credits with federal tax credits to substantially increase the financial benefit.

\section{Tax Abatement or Deferral}

Property tax is one of the largest single expenses for building owners. Properties are taxed on value of the underlying land as well as the improvements thereon, such as buildings. The value of the land is tied to its potential for development, the so-called "highest and best use". This can often lead the owner to tear down an existing historic structure and replace it with a more intensive use. On the other hand, when buildings are rehabilitated or restored, their assessed value increases, thus increasing their taxes. This can discourage owners from maintaining or improving their properties.

Many state legislatures have addressed these problems by creating abatement programs, where the assessed value of a historic building is frozen at its pre-rehabilitation level for a certain number of years. Although the program details such as the type of properties that qualify, minimum investment requirements, and the length of the abatement period vary from state to state, the overall approach adopted in Georgia is typical ${ }^{42}$. To qualify for the abatement, a property must be eligible for listing in the Georgia Register of Historic Places and undergo substantial rehabilitation. Substantial rehabilitation is defined as an increase in the fair market value of the building or structure by 55 percent for owner occupied residential property, 100 percent for income-producing properties, and 75 percent for income-producing property used primarily as residential property. Finally, the work must meet the rehabilitation standards promulgated by the Georgia Department of Natural Resources. Once the administrative process for certification is complete, the owner presents the certificate to county board of tax assessors and the assessed value of the property upon which taxes are based is frozen for eight consecutive years. In the ninth year, the assessment is adjusted to a point halfway between the frozen value and the current fair market value. In the tenth year, the assessment is placed at fair market value. Should the property lose the historic or architectural features that made it eligible during the period of the abatement, the amount of the taxes which have been abated, along with interest, become due as a penalty.

On April 11, 1990, the Governor of Georgia signed into effect a local option act property tax deferment for historic resources designated under an approved local ordinance listed either by the State Register or the National Register of Historic Places. This incentive program does not require

\footnotetext{
42 Rehabilitated Historic Property Act of 1989, O.C.G.A. Section 48-5-7.2.
}

rehabilitation. The ordinance making this option available in Athens, Georgia was signed in January, $1995^{43}$. The program provides an eight-year freeze on property tax assessments rising in the ninth year by $50 \%$ of the difference between the first-year value and the current fair market value. In the tenth and following years, the property is assessed at its fair market value. When the application is accepted the value frozen on the tax digest is the higher of the property's acquisition cost or the value at the time of the application is submitted to the Board of Assessors. If the property is in an area with residential zoning, the preferential assessment is available only to properties that conform to the zoning ordinance. Certification requires: 1) A certification from the Georgia Department of Natural Resources as being listed on either the National Register of Historic Places or the Georgia Register of Historic Places, as either an individually listed property or a contributing resource in a listed district, and 2) A certification from the Athens-Clarke County Planning Department that the property is either a locally designated landmark or a contributing building within a locally designated historic district. Properties that are also eligible for the State Rehabilitation Act freeze may not take the benefits of both simultaneously ${ }^{44}$. Since 1995 , 538 properties have qualified for this tax deferment under the ordinance ${ }^{45}$.

\section{Sales Tax}

With the unpopularity of property taxes, the simplicity and perceived fairness of sales taxes have made the Special Purpose Local Option Sales Tax (SPLOST) a popular method of financing historic preservation and other improvement projects ${ }^{46}$. Georgia law allows local jurisdictions to use sales tax proceeds as funding for capital projects that would otherwise be paid for with the general fund and property tax revenues, presumably increasing the property tax. Athens has employed this revenue raising mechanism several times. A SPLOST is imposed through a referendum of Athens-Clarke County voters. Although used for a wide variety of projects, historic properties have been recipients of this program since its inception. A recent example is their use in upgrading the heating, ventilation, and air conditioning standards of the historic African-American Morton Theatre while maintaining the historic preservation of

\footnotetext{
43 "Athens-Clarke County Local Option Tax Incentive for Historic Property", accessed May 10, 2020, https://www. athensclarkecounty.com/DocumentCenter/View/243/HistoricProperty-Tax-Assessment-Freeze?bidId=.

44 "Athens-Clarke County Local Option Tax Incentive for Historic Property", Athens Clark County, accessed May 20, 2020, https://athensclarkecounty.com/DocumentCenter/View/243/ Historic-Property-Tax-Assessment-Freeze?bidId=.

45 Amber Eskew, Athens Clarke County Planning Department, in an email message to the author, May 22, 2020.

46 O.C.G.A. Section 48-8 -110, et seq.
} 
the facility. The building had been restored originally using SPLOST funds in 1987. The tax revenue also funded the development of a history-based landscape and garden in accordance with the restoration master plan to complement the earlier restoration of the historic WareLyndon House and enhance the facility as an interpretive house museum. The formal garden enhances the cultural tourism offerings of the historic facility. This project continued the work done in 1999 to preserve the WareLyndon House as a historic site and the last remaining home from its original neighborhood. Other examples of the use of these funds includes renovations to the TaylorGrady and Church-Waddel-Brumby House museums and restoration of the Gospel Pilgrim Cemetery ${ }^{47}$ (Figures 12 and 13).

\section{REGULATORY INCENTIVES FOR REHABILITATION OF HISTORIC BUILDINGS}

To protect the public from unsafe conditions, most jurisdictions have adopted codes and standards that specify how buildings are to be constructed and used. These codes focus on new construction and substantial rehabilitation and require up-to-date materials and construction techniques to ensure public safety. The cost of fully complying with these codes when renovating historic properties can be significant, to the point of making their rehabilitation economically infeasible. Similar rehabilitation projects in different jurisdictions can vary in cost by as much as a million dollars because of building code differences. To address this problem, professional associations of building code officials and state governments have developed new code provisions that provide more flexibility in design, materials and construction systems enabling historic buildings to effectively meet standards without reducing the overall level of safety. Georgia has enacted legislation in the area ${ }^{48}$. The Athens-Clarke County code includes provision allowing for historic buildings to preserve their historic character-defining features while achieving an equivalent level of safety as contemporary building codes. The intent is to "provide for the upgrading of the safety features of the building or structure to provide a practical level of safety to the public and surrounding property" and "provide guidance regarding acceptable alternative solutions and to stimulate enforcement authorities to utilize alternative compliance concepts

\footnotetext{
47 "Special Purpose Local Option Sales Tax (SPLOST)", AthensClarke County, Georgia, accessed May 10, 2020, https://www. accgov.com/splost.

48 "The Uniform Act for the Application of Building and Fire Related Codes to Existing Buildings", O.C.G.A. Section 8-2-200, et seq. and "Buildings presenting special hazards to persons or property”, O.C.G.A. Section 825-2-13.
}

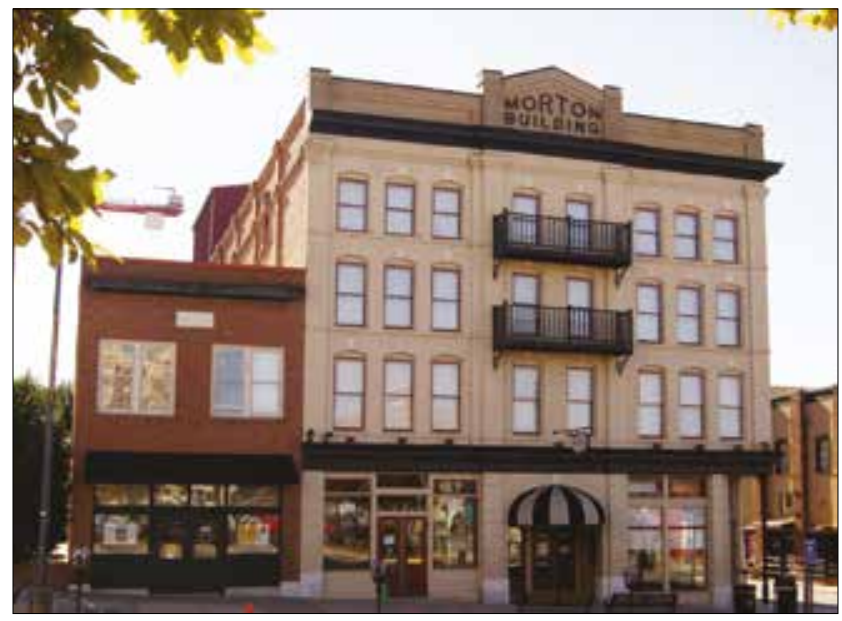

Figure 12. Morton Building, 1910, exterior view. The building houses the Morton Theatre, one of the oldest surviving vaudeville theatres in the United States built, owned, and operated by an African-American. The building housed not only the theatre, but also many of Athens' black doctors, dentists, pharmacists and other professionals. Restored 1993. Arts Division, Athens-Clarke County Leisure Services Department, https://www.mortontheatre. com/photo-gallery. / Morton Binası, 1910, dış görünüşü. Bina, bir Afrikal-Amerikalı tarafindan inşa edilen, işletilen Amerika Birleşik Devletleri'nde hayatta kalan en eski vodvil tiyatrolarından biri. Bina sadece tiyatroyu değil, aynı zamanda Atina'daki siyah doktorlar, diş hekimlerini, eczacılart ve diğer profesyonelleri de barındirlyordu. Yapı, 1993 yılında restore edilmiștir.

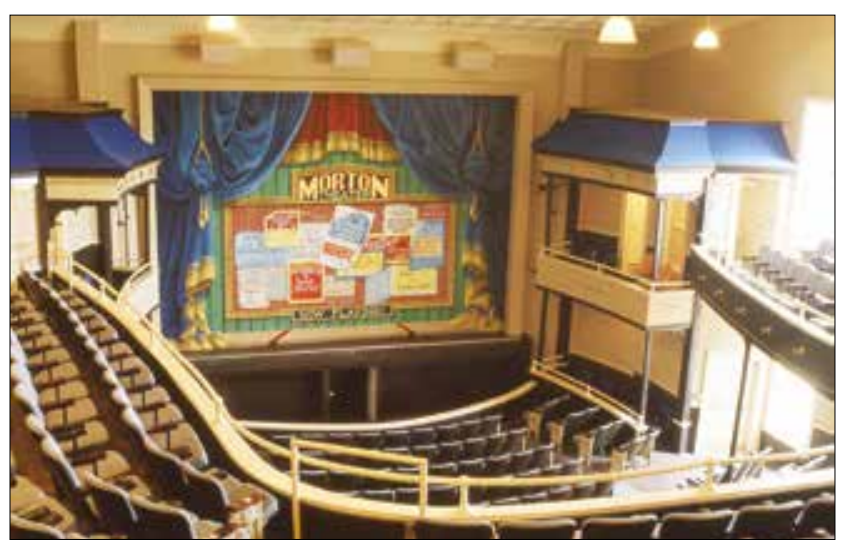

Figure 13. Morton Building 1910, interior view. Arts Division, Athens-Clarke County Leisure Services Department, https:// www.mortontheatre.com/photo-gallery. / Morton Binası, 1910, iç görünüşü.

whenever practical to permit the continued use of existing buildings and structures without overly restrictive financial burdens owners or occupants"49. Officials of the Building Inspections Department and Fire Marshall have worked collaboratively with the Planning Department to find appropriate life safety and building code flexibility for historic properties, particularly in downtown Athens ${ }^{50}$.

\footnotetext{
49 The Code of Athens-Clarke County, Georgia, Section 7-5-1, et seq.

50 Bruce Lonnee, Athens Clarke County Planning Department, in an email message to the author, May 22, 2020.
} 


\section{Brownfields}

One impediment to the rehabilitation of historic commercial and industrial properties is the environmental pollution of sites caused by prior uses. Hazardous substances, pollutants, or contaminants affect more than 450,000 properties in the United States. Among the many types of properties affected are gasoline stations, utility sites, dry cleaners, metal plating plants, paint manufactures and other chemical plants, and print shops. These often-abandoned sites not only create health and safety concerns, but result in neighborhood blight, a depressed tax base, and an impediment to redevelopment. Benefits of rehabilitating these sites, referred to as "brownfields development," include environmental protection, new jobs and housing, blight elimination, increased tax base, and sprawl reduction. Beginning in 1992, the Federal Environmental Protection Agency began a brownfields program that provides grants and liability relief to assist in brownfield clean-up. The federal program did not reach all eligible sites, particularly smaller properties. In 1996 the Georgia General Assembly passed the Hazardous Site Reuse and Redevelopment Act (Brownfields Act), creating a state brownfield program managed by the Environmental Protection Division (EPD) of the Department of Natural Resources. Property purchasers who enter into a contract with the state and agree clean up the property are provided relief of liability for the prior pollution and tax incentives that can reduce property taxes for 10 years or until clean-up costs are recouped ${ }^{51}$. An example of a successful brownfield clean-up in Athens utilizing the Georgia Brownfield Program involves New Way Cleaners, a 1946 mid-century modern structure located on a main thoroughfare in an area with a number of important historic structures. The building sat abandoned for six years before the brownfield redevelopment began. Chemical residue from the prior business was addressed and the property was granted a limitation of liability by EPD. The building was rehabilitated employing sustainable construction practices in 2015 by Half-Moon Outfitters, an outdoor gear retailer. The successful project contributed to the ongoing regeneration of the $\operatorname{area}^{52}$ (Figure 14).

\section{The Main Street Program}

In 1980, Athens was chosen as one of 25 communities in the United States to participate in a pilot program established by the National Trust for Historic Preservation to catalyze

\footnotetext{
51 "Brownfield", Environmental Protection Division, accessed May 20, 2020, https://epd.georgia.gov/land-protection-branch/ hazardous-waste/brownfield.

52 Kristen Morales, "Half-Moon Outfitters Has a New Way to Renovate Dry Cleaners" Flagpole, accessed May 20, 2020, https://flagpole.com/news/news-features/2015/02/25/halfmoon-outfitters-has-a-new-way-to-renovate-dry-cleaners/.
}

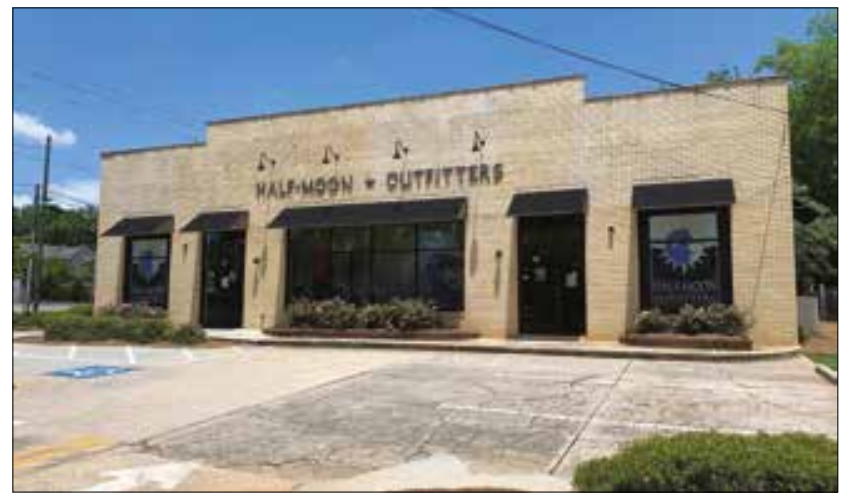

Figure 14. New Way Cleaners, 1946. This mid-century modern structure was used as a dry cleaner from 1946 until 2009. It remained undeveloped until 2014 when the hazardous chemicals from the drycleaning process were addressed the property redeveloped under the Georgia Brownfields Program using green building approaches. It is occupied by Half-Moon Outfitters, an outdoor recreations store. Photo by the author. / New Way Temizleme, 1946. Bu 1950'lerin modern yapısı 1946'dan 2009'a kadar kuru temizleme işleviyle kullanılmıştır. Kuru temizleme kimyasallarının zararları sebebiyle 2014 yıkına kadar kullanılmayan yapı, yeşil bina yaklaşımıyla Georgia Brownfields Programı tarafindan yeniden işlevlendirilmiştir. Half Moon giyim mağazası tarafindan kullanılmaktadır.

community revitalization in the historic downtown areas of small cities around the county. The National Main Street Program focuses on a four-point approach for downtown business districts involving design, promotion, economic restructuring, and organization. The Georgia program, housed in the State Department of Community Affairs, has grown to more than 100 participating communities in the state that use private-public partnerships to stimulate historic preservation, small business development, job creation, leveraged public investment and increased tourism. The program is administered locally by the Athens Downtown Development Authority, which was created by state legislation in 1977 to promote economic development, redevelopment, and rehabilitation in the downtown area. Governed by a seven-person board appointed by the county Board of Commissioners, it serves as a liaison between the downtown business community and the local government. When an enclosed regional mall was opened in 1981 in the western part of the county, the demise of downtown was widely-predicted after large department stores and other commercial established moved to the new facility. However, in 2020 downtown Athens is a vital district of restaurants and bars, retail, music and theatre venues, government offices, and, increasingly, apartments and condominiums. The mall on the other hand, has fallen on hard times, with three large department stores and other stores closing. The success of downtown owes much to the Main Street Program's focus on preserving historic character and fostering economic opportunity. Much of the downtown is listed in the National Register of Historic Places and part is a designated local historic district ${ }^{53}$.

$\overline{53}$ Downtown Athens, Athens Downtown Development Authority, 


\section{GRANTS FOR HISTORIC PRESERVATION}

Direct grants from the government are one way of reducing rehabilitation costs. Grants can be superior to tax incentives in a number of ways. They can be more closely targeted to certain types of historic properties and particular program users. Unlike tax incentives, grants are not limited to those with high tax liabilities but can focus on properties of low and moderate-income owners. Grants also tend to provide better control over the quality of work. While the impact of grants on state and federal budgets is more predictable than incentive programs, grants depend on yearly appropriations and are more subject to reductions or elimination (Sewell 1996: 109).

The National Historic Preservation Act of $1966^{54}$, provides for federal grants and grants to the states which may be passed through to local governments or individuals. In practice, however, the limited appropriations by Congress have been used primarily to support the administrative infrastructure on the federal and state levels. Since 1980, only a relatively small amount has been awarded in grants, and these primarily to governmental entities.

The federal government also provides grants for other specific purposes to states and local governments, but some of them may be used for historic preservation. A number of significant grants programs for state and local governments are funded under the Department of Housing and Urban Development (HUD) Act. Community Development Block Grants (CDBG) have been used extensively to help communities with economic development, job opportunities and housing rehabilitation. Funds under this program have been used not only for infrastructure improvements, but also for direct rehabilitation grants for low-income homeowners. Hands On Athens (HOA) is a neighborhood revitalization initiative of the nonprofit Historic Athens that assists low-income homeowners with home maintenance projects in homes that are 50 years or older. Focusing primarily on Hancock Corridor, East Athens, and Newtown, its overall goal is neighborhood revitalization, keeping neighborhoods intact through safe and habitable homes. Residents of these areas are able to apply if they own and plan to continue living in their homes, can document income below 80 percent of the median income level, and reside in homes that are approximately 50 years old or older. Common projects include floor and ceiling repair, minor plumbing, roof/gutter repair, landscaping, and painting. HOA receives funding through Community Development Block Grant funds

accessed May 20, 2020, https://downtownathensga.org/; "Georgia Main Street", Georgia Department of Community Affairs, accessed May 20, 2020, http://www.georgiamainstreet.org/.

5416 U.S.C. $\S 470$ et. seq. administered by the Athens-Clarke County Housing \& Community Development Department. Hands On Athens also relies upon local construction partners, volunteer group, and private donations whenever possible to extend the government funds ${ }^{55}$. These funds allow lowincome residents to remain in their homes will preserving their properties from deterioration and maintaining the character of the historic district.

A number of states make appropriations for direct grants to historic preservation projects. Generally individual grants are made only to state agencies, local governments and private nonprofit organizations. However, economic incentives work in the public sector as well as the private sector by reducing the overall cost of the project. In addition to general appropriations and bond issues, state governments have raised funds for preservation activities through lotteries, taxes on real estate, mortgage fees, gambling, cigarettes, hotels/motels, and limited partnerships as well as vehicle license plate revenues and litigation proceeds ${ }^{56}$. In addition to programs directed specifically toward historic preservation, states offer a wide variety of local development programs whose resources can often be directed toward preservation activities $^{57}$.

In 1994, the Georgia legislature created the Georgia Heritage Grant Program by making appropriations for grants which serve as seed money for preservation of historic properties and archaeological sites. The matching grants are awarded on a competitive basis statewide to local governments and nonprofit organizations to for preservation of properties eligible for listing in the Georgia Register of Historic Places. The grants are funded from the sale of special vehicle license plates, from which a percentage goes into this fund. Since 1994 the program has awarded more than $\$ 3.5$ million for preservation projects throughout the state. Direct state appropriations and Georgia Heritage Grants have assisted the preservation of a number of important

\footnotetext{
55 "Hands of Athens", Historic Athens, accessed May 10, 2020, https://www.historicathens.com/hands-on-athens; "Hands on Athens Gets Handy on Hancock", Patch, Athens, GA, accessed May 10, 2020, https://patch.com/georgia/athens/hands-onathens-gets-handy-on-hancock.

56 Beaumont, Constance, Smart States, Better Communities, National Trust for Historic Preservation, 1996, 71-76.

57 One example is Georgia's Redevelopment Fund which provides matching grants to communities for downtown development projects, historic preservation projects such as improvements to historic courthouses and city halls, tourism activities, and community facilities such as museums and community centers. Although eligible, Athens has not received one of these grants. See "Redevelopment Fund Fact Sheet 2017", Georgia Department of Community Affairs, accessed May 20, 2020, https://www.dca.ga.gov/sites/default/files/2017_rdf_fact_ sheet_rev_4-18.pdf.
} 
historic structures in Athens, including: The Franklin House, Joseph Henry Lumpkin House, Seney-Stovall Chapel, Morgan House, Lucy Cobb Institute, Morton Theatre, and Old Clarke County Jail ${ }^{58}$.

\section{EDUCATION AND ADVOCACY}

In many American cities, private nonprofit organizations carry much of the burden of informing the public of the benefits of historic preservation and advocating for the preservation of heritage resources in the local community. Where the local government has established a formal preservation structure, nonprofits can serve as a support for those agencies or offices and often partner with them to accomplish preservation goals. Although the preservation ordinance in Athens specifies that the Historic Preservation Commission is authorized to "conduct an educational program on historic properties located within its historic preservation jurisdiction", the regulatory functions of the Commission consume most of its attention. The Commission, with the support of the city's planning staff, does maintain a web presence and issues annual reports, which provide information on community resources, reasons for their preservation, the process followed by the local government in carrying out its responsibilities, and the actions it has taken during the year ${ }^{59}$.

\section{Historic Athens}

While public efforts are important, it is the local preservation nonprofit, Historic Athens, Inc., that has taken the lead role in local public education and advocacy since its founding in 1967 (as the Athens-Clarke Heritage Foundation), nearly twenty years before the City enacted its historic preservation ordinance ${ }^{60}$. The impetus for the organization's establishment was public concern for the demolition of historic buildings and neighborhoods as the city developed dramatically during the 1960s. The first nonprofit organization to be established in the early 1960s specifically for the purpose of historic preservation was the Society of the Preservation of Old Athens (SPOA). While it was successful in raising awareness of the need to preserve several community landmarks, after a few years it became inactive. The threat to the historic Church-Waddell-Brumby House by the local government's federally-funded urban renewal project galvanized several former members of SPOA to

\footnotetext{
58 Melanie Holthaus, Georgia Department of Natural Resources, in an email message to the author, May 20, 2020.

59 Historic Preservation Commission Annual Reports, 2016-2019, accessed May 10, 2020, https://www.athensclarkecounty. com/208/Historic-Preservation.

60 The name of the organization was changed in 2019 to better reflect its broad community agenda.
}

found the Athens-Clarke Heritage Foundation (ACHF) in 1967. The urban renewal authority agreed not to demolish the building if the Foundation was able to move it to another site nearby. The nonprofit was able to secure support from private fundraising and monies from local and federal governments to purchase the house from the authority and move it just days before it was to be demolished. The structure was restored and opened to the public in 1972 (Ann 1979; Waters 2002). Historic Athens is incorporated under Georgia law and has federal tax-exempt status. This permits the organization to pay no taxes on income derived from its preservation and educational activities and permits individuals who donate funds to the organizations to claim state and federal income tax deductions for gifts to the organization. These donations have been key to supporting its activities.

Over the years, Historic Athens has diversified its preservation efforts. It has been instrumental in securing grants for survey, planning and nomination of properties for national and local designation, developing a fund to provide direct financial assistance for preservation projects, and established the Hands-on Athens program mentioned above. It continues its partnership with local government in many ways. After securing the preservation of the Church-Waddel-Brumby House, the foundation deeded the house to the City and leased it back. It is operated at the official Welcome Center for the city through agreements with the City and the Athens Convention and Visitors Bureau. In addition, the structure serves as a house museum interpreting domestic life in Athens in the $1820 \mathrm{~s}^{61}$. The Foundation entered into a similar lease agreement with the City to secure the preservation of a 1901 fire station, which it utilizes as its headquarters and education center ${ }^{62}$. The Foundation and Welcome Center operate Classic City Tours, which provides a variety of fixed and custom heritage tours in the community. Additionally, they offer free, downloadable self-guided tours for visitors and residents focusing on resources such as music history, Downtown Athens, and the Milledge Avenue, Dearing Street and Cobbham historic districts, a variety of African-American historic sites, the University of Georgia Campus, and Civil War history $\operatorname{sites}^{63}$.

\footnotetext{
${ }^{61}$ Athens Welcome Center, accessed May 10, 2020, https://www. athenswelcomecenter.com/house-museum.

62 The city owns two other historic structures that serve as house museums: the Taylor-Grady House, operated by the Athens Junior League as a museum house and event venue, accessed May 20,2020, http://www.taylorgradyhouse.com/, and the Ware-Lyndon House, which is part of the Lyndon House Arts Center, accessed May 20, 2020, https://www.accgov.com/ Facilities/Facility/Details/29.

63 "Classic City Tours", Athens Welcome Center, Accessed May 20, 2020, https://www.athenswelcomecenter.com/tours.
} 
Among other educational and advocacy activities of the organization are special neighborhood home tours, a preservation awards program, walking tours of historic neighborhoods, an annual list of endangered properties, a series of educational seminars, lectures, workshops and social events to engage community interest and support for preservation. Representatives of the organization also provide input to the community comprehensive plan and other public initiatives and advocate for best preservation practices at hearings conducted by the Historic Preservation Commission and local governing body ${ }^{64}$.

\section{Historic Cobbham Foundation}

Another nonprofit preservation organization in Athens is focused on a single historic neighborhood-the Historic Cobbham Foundation. The Cobbham neighborhood was laid out in 1834 and reflects a wide range of architectural types and styles from the 19th and early 20th centuries. Like Historic Athens, the organization was founded in 1972 by local residents reacting to hospital and church expansions, commercial instutions, and conversion, conversion of homes from single family occupancy to multi-family rental properties. Originally an informal community association, it was formally incorporated as a nonprofit corporation in 1977. The organization has advocated for National Register listing, local historic district designation, zoning changes to encourage preservation of the housing stock, preservation of specific landmark buildings, and construction of community amenities. Members spearheaded efforts to acquired the Old Clarke County Jail to ensure its preservation and encouraged the University of Georgia to restore an historic school property in the neighborhood-the Lucy Cobb Institute. The organization continues as a force to preserve the livability and historic character of the neighborhood through publications, tours, and other educational outreach efforts and engages local government on public initiatives that affect the quality of life of the residents ${ }^{65}$.

\section{Watson-Brown Foundation}

Athens has also benefitted from the work of a private foundation based in Thompson, Georgia - the WatsonBrown Foundation. Established by philanthropist Walter J. Brown in 1970 for educational purposes, the foundation owns and operates three historic sites in Georgia, offers a grant program to encourage scholarship on the U.S. South, and supports historic preservation. One of the

\footnotetext{
${ }_{64}$ Historic Athens, accessed May 10, 2020, https://www. historicathens.com/.

${ }_{65}$ Historic Cobbham Foundation, accessed May 10, 2020, http:// www.historiccobbhamfoundation.org/.
}

foundation's historic sites, the Thomas R. R. Cobb House, is located in Athens. The foundation utilizes the house and a variety of ways to present 19th century Southern history. The first floor is restored and furnished as it might have looked in the 1852-1862 period with original pieces from the Cobb and related Athens families. The second-floor houses offices, classrooms and temporary exhibits. The Greek Revival House was the home of Thomas R. R. Cobb, a successful and influential 19th century legal scholar, civic leader, plantation owner, and military officer who enlarged a modest home several times in the 1940s and 1850s to create an impressive mansion. The house was threatened with destruction in the 1980s during redevelopment of property by a church that owned it at the time but was purchased by the Stone Mountain Memorial Association and moved to Stone Mountain Park near Atlanta. Originally intended to be part of a recreated "plantation", it was never restored, but sat deteriorating for nearly 20 years. In 2005, the WatsonBrown Foundation moved the house back to Athens to a location near its original site and restored $\mathrm{it}^{66}$. The T.R.R. Cobb house is open to the public as a museum house and educational center. To assist visits by school groups, they charge no admission and reimburse expenses related to the students' visit.

The Foundation has also developed an innovative program to teach young people about history, civic responsibility, and philanthropy - the Junior Board of Trustees. A group of seven to thirteen high school students seek out and determine historic preservation opportunities in Northeast Georgia through monthly meetings, site visits. Under the supervision of Foundation staff, they review applications from nonprofit organizations and award grants from a $\$ 33,000$ annual fund for historic preservation projects. Recent Junior Foundation grants in Athens have supported a site history, mapping and National Register nomination of the historic Beech Haven cultural landscape, filming historic walking tours, restoration of the African-American Chestnut Grove School, production of brochures, maps, signs and website improvements for historic Oconee Hill Cemetery, purchase of antique door locks and re-creation historic faux graining on interior woodwork to the ChurchWaddel-Brumby House ${ }^{67}$.

\footnotetext{
${ }^{66}$ A YouTube video illustrates the move from Atlanta to Athens and its reconstruction. The T.R.R. Cobb House Restoration Project, May 5, 2009, YouTube video, 5:00, https://www. youtube.com $/$ watch? $\mathrm{v}=\mathrm{dY}$ j j9ndT8iE.

67 T. R. R. Cobb House, accessed May 20, 2020, http://www. trrcobbhouse.org/.
} 


\section{University of Georgia}

The Historic Preservation Program at the University of Georgia has also played a significant role in preservation education and advocacy since classes began on campus in 1973. First offered as a seminar in the School of Environmental Design (now College of Environment and Design), two classes, Introduction to Historic Preservation and Preservation Planning, were offered in 1975 as an area of concentration in the Master of Landscape Architecture curriculum. The University authorized the creation of a two-year Master of Historic Preservation (MHP) degree in 1982 and the first five students were admitted. From the beginning, the program utilized community engagement as an opportunity serve the University's public service mission and as a way to enhance student learning through handson experiences. As the number of faculty, classes and subjects increased, so did the impact on the community. Under the supervision of faculty, students conducted historical research and architectural surveys, completed National Register nominations and planning documents, undertook economic studies, prepared historic structure reports, and assisted local nonprofits on a wide variety of community projects through internships. In 2020, program offerings included, in addition the MHP degree, a dual law and preservation degree (JD/MHP), graduate and undergraduate certificates in Historic Preservation Studies for students pursuing other degrees, a Certificate in Cultural Landscape Conservation, an undergraduate minor in historic preservation, and two five-year programs that allow majors in History or Classics to receive both a bachelor's degree in their major subject and an MHP degree upon completion. In addition to the community impact from college courses, the Student Historic Preservation Organization has participated in many community preservation projects on a volunteer basis. Faculty have also served on the City's Historic Preservation Commission and on the boards of directors of local nonprofits and neighborhood organizations. The program has also had an impact on the City through its graduates who have remained in Athens and are employed locally in public, private and nonprofit organizations. While the University has contributed to the overall character of Athens as a college town, it has also contributed to the development of an appreciation of historic preservation within the community ${ }^{68}$.

\section{CONCLUSION}

This case study has not included an exhaustive review of the United States' heritage conservation laws and programs but has attempted to provide a selective overview of the various governmental, nonprofit and private preservation initiatives that comprise one community's experience. By employing the many public and private programs and tools described above, Athens, Georgia has been able to retain much of its character as an historic American college town. While federal and state laws and programs are important, building a culture of preservation is a community matter. Thomas "Tip" O'Neill, former Speaker of the United States House of Representative is quoted as saying that "all politics is local." Those active in heritage conservation in the United States would posit that "all preservation is local." Where successful, it relies on a complex interaction of individual activists, nonprofit organizations, and private investors working in a framework of governmental regulation and incentives. That has been true of Athens. It is not a perfectly preserved historic village, but its historic core, including the university, downtown, and nearby residential neighborhoods and commercial districts, has maintained a sense of place characterized by its aesthetics, architecture, and tradition that is recognized by visitors, local residents, university students, faculty, staff, and alumni. Maintaining that character as the community continues to grow and develops will be an ongoing challenge, but many of the current preservation tools can be applied along with new approaches to achieve that end (Figure 15).

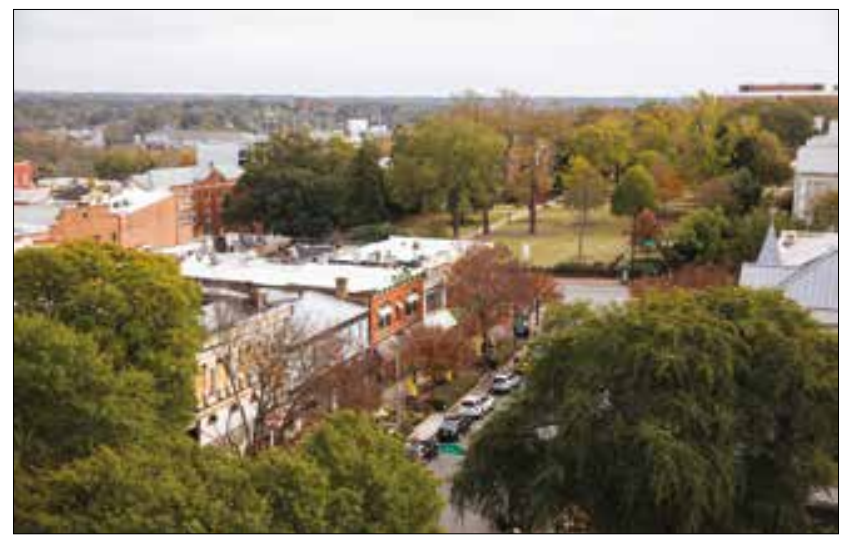

Figure 15. Overhead view of College Square in downtown Athens with the North Campus Quadrangle in the background. Photo by Dorothy Kozlowski, 2017. Credit University of Georgia Marketing and Communications. / Üniversite meydanina üstten bakış. 


\section{REFERENCES}

ANN D. 1979.

"The Athens-Clarke Heritage Foundation", The Georgia Historical Quarterly 63, no. 1.

BRADFORD J. W. AND RICHARD J. R. 1994.

Preparing a Historic Preservation Plan, 4 (American Planning Association, 1994).

BYERS E. 2005.

The Conservation Handbook, The Trust for Public Land, at 8.

Clarke County Georgia Deed Records, Book 1264, Page 128 and Book 4788, Page 26, 2018.

CULLISON, D. AND LOCKART J.R. 1993.

Held in Trust: Historic Buildings Owned by the State of Georgia: A Report Submitted to the Office of Historic Preservation, Georgia Department of Natural Resources and the Georgia Trust for Historic Preservation. Dept. of Natural Resources, Historic Preservation Division.

GUMPRECHT, B. 2003.

“The American College Town." Geographical Review 93 (1): 51-80.

LISTOKIN, D. 1997.

"Growth Management and Historic Preservation: Best Practices for Synthesis”, 29 The Urban Lawyer 202.

Penn Central Transportation Co. v. New York City, 438 U.S. 105 (1978).

REAP, J. K. 2001.

Athens, a Pictorial History. 3rd Ed. Donning Co.

SEWELL, J.A. 1996.

State Income Tax Incentives Versus Grants: Which Are Better? in Constance Beaumont, Smart States, Better Communities.

TYLER, NORMAN, ILENE R. TYLER, AND TED LI- GIBEL. 2018.

Historic Preservation: An Introduction to Its History, Principles, and Practice. Third edition. W.W. Norton \& Company, 47.
URL-1: "X Amendment", Legal Information Institute, Cornell University, accessed May 20, 2010, https:// www.law. cornell.edu/constitution/tenth amendment. Georgia NHL Henry W. Grady House, National Archives Catalog, accessed May 20, 2020, https://catalog.archives. gov/id/93206752. URL-2: "Local US Governments,"

National League of Cities, accessed May 10, 2020, https://www.nlc.org/local-us-governments.

URL-3: Historic American Buildings Survey/Historic American Engineering Record/Historic American Landscapes Sur- vey, accessed May 10, 2020, https:// www.loc.gov/pic- tures/collection/hh/, and Linley, John. The Georgia Cata- log, Historic American Buildings Survey: A Guide to the Architecture of the State. Publications / The Wormsloe Foundation: V. 15. University of Georgia Press, 1982.

\section{URL-4: National Register Bulletin 24,}

U.S. Department of the Interior, National Park Service, accessed May 10, 2020, https://www.nps.gov/subjects/ nationalregister/upload/NRB24-Complete_Part1.pdf.

URL-5: "Roots of the National Historic Landmarks Program", National Park Service, Accessed May 25, 2020, https:// www.nps.gov/articles/roots-of-thenational-histor- ic-landmarks-program.htm.

URL-6: https://www.nps.gov/subjects/nationalregister/ index. htm.

URL-7: https://athensclarkecounty.com/855/

Community-Assess- ment.

URL-8: https://ced.uga.edu/pso/findit/.

URL-9: https://www.nps.gov/subjects/nationalregister/ upload/ NRB-15_web508.pdf.

URL-10: https://georgiashpo.org/nominationprocess.

URL-11: http://www.nationalregisterofhistoricplaces. $\mathrm{com} / \mathrm{ga} /$ clarke/state.html.

URL-12: https://athensclarkecounty.com/812/ Guidelines-Exam- ples.

URL-13: https://www.athensclarkecounty.com/ DocumentCenter/View/288/HP---Design-Guidelines--Downtown?bi- dId $=$.

URL-14: https://athensclarkecounty.com/208/HistoricPreserva- tion. 
URL-15: https://www.athensclarkecounty.com/ DocumentCenter/ View/19722/HP-Map---LocalHistoric-Districts--Land- marks?bidId=

URL-16: https://georgiashpo.org/

statepreservationplan.

URL-17: https://athensclarkecounty. com/DocumentCenter/ View/351/ACCPreservationPlan_1.

URL-18: https://www.athensclarkecounty.com/844/ Comprehen- sive-Plan.

URL-19: https://www.architects.uga.edu/home/ historic-preserva- tion.

URL-20: https://www.irs.gov/charities-non-profits/ charitable-or- ganizations.

URL-21: https://forum.savingplaces.org/learn/ fundamentals/pres- ervation-law/easements

URL-22: https://forum.savingplaces.org/learn/ fundamentals/pres- ervation-law/easements

URL-23: https:/www.nps.gov/tps/standards/ rehabilitation/rehab/ stand.htm.

URL-24: https://www.nps.gov/tps/tax-incentives/ taxdocs/tax-in- centives-2019annual.pdf.

URL-25: https:/georgiashpo.org/tax-statecredit

URL-26: https://www.athensclarkecounty.com/ DocumentCenter/View/243/Historic-Property-TaxAssessment-Freeze?bi- $\mathrm{dId}=$

URL-27: https://athensclarkecounty.com/ DocumentCenter/View/243/Historic-Property-TaxAssessment-Freeze?bi- dId=

URL-28: https://www.accgov.com/splost.

URL-29: https://epd.georgia.gov/land-protectionbranch/hazard- ous-waste/brownfield.

URL-30: https://epd.georgia.gov/land-protectionbranch/hazard- ous-waste/brownfield.

URL-31: https://flagpole.com/news/newsfeatures/2015/02/25/ half-moon-outfitters-has-a-newway-to-renovate-dry- cleaners/..
URL-32: http://www.georgiamainstreet.org/ https:// www.historicathens.com/hands-on-athens https://www.dca.ga.gov/sites/default/files/2017_rdf_ fact_sheet_rev_4-18.pdf.

URL-33: https://www.athensclarkecounty.com/208/ Historic-Pres- ervation.

URL-34: https://www.athenswelcomecenter.com/housemuseum https://www.athenswelcomecenter.com/tours.

URL-35: https://www.historicathens.com/ http://www. historiccobbhamfoundation.org/ https://www.youtube. com/watch? $v=d Y$ j9ndT8iE. http://www.trrcobbhouse. org/.

URL-36: https:/ced.uga.edu/programs/mhp/. 